
International scientific and practical conference

\section{CUTTING EDGE-SCIENCE}

January, 2021 Shawnee, USA

Conference Proceedings

Primedia E-launch

Shawnee, USA 


\section{PRIMEDIA E-LAUNCH}

International scientific and practical conference

\section{CUTTING EDGE-SCIENCE}

January, 2021 Shawnee, USA

Conference Proceedings

Science editor: G. Kolne

Copyright (C) 2021

By Primedia E-launch LLC

All rights reserved.

Available at virtualconferences.press

Published Primedia E-launch LLC.

Shawnee, USA

ISBN 978-1-64945-245-0

DOI: http://doi.org/10.37057/U_7

Primedia E-launch LLC, 5518 Flint St, Shawnee, 66203, USA 


\section{AGRICULTURAL SCIENCES}

Ruziev Hamrokul Jurayevich

FACTORS TO INCREASE THE EFFICIENCY OF THE MARKET OF MODERN

SERVICES IN THE AGRO-INDUSTRY.

\section{HISTORICAL SCIENCES}

Doctor of Political Sciences K.A.Yunusov

THEORETICAL AND METHODOLOGICAL ASPECTS OF STUDYING THE HISTORY OF

CENTRAL ASIA, ESPECIALLY, UZBEKISTAN

Tashmuradova Sarvinoz Quvondiq qizi, Bengmatov Alibek Kahramon oglu

THE ROLE OF THE KUSHAN EMPIRE IN WORLD CIVILIZATION....

\section{LITERATURE SCIENCES}

Khudaybergenova Khosiyat Kahramonovna, Matyakubova Nazira Azatovna,

Rakhimova Dilafruz Akhmedovna

AGAHI - IS ONE MEMBER OF THE UZBEK CLASSIC LITERATURE.

\section{MEDICAL SCIENCES}

Abdukadirova M.A., Khikmatullaeva A.S., Jumanov B.A.

ANALYSIS OF CLINICAL MANIFESTATIONS OF COVID-19.

Arifov S.S., Kalandarova D.A., Orifov S.S.

ASSESSMENT OF THE ROLE OF HEARING AIDS IN REHABILITATION OF PATIENTS

WITH THE SENSORINEURAL HEARING LOSS

Ikramov G.A., Yuldashev A.A., Mardonova N.P., Olimjonova G.G.

RESTORATION OF POSTOPERATIVE JAW BONE DEFECTS USING

OSTEOMATERIALS, PLATELET-RICH PLASMA.

Komiljon Abdukarimovich Yuldashev, Jumanazar Toshboevich Nuraev

SEROLOGICAL PICTURE IN CASE OF FALSE POSITIVE BLOOD REACTIONS

(FPBR)

Madjidova Y.N., Usmanova D.D., Mamatalieva J.A.

TACTICS OF CARING FOR PATIENTS WITH ACUTE DISORDERS OF CEREBRAL

CIRCULATION IN FERGANA

Mirzakarimov Bakhromjon Halimjonovich, Akilov Khabibullo Ataullaevich

CORRECTION OF PIGEON CHEST IN CHILDREN

Muhsimova N.R., Razzoqov D.A.

PSORIATIK ARTRITDA ALKOGOLSIZ YOGLI JIGAR KASALLIGINING

RIVOJLANISHI VA UNING ISTIQBOLLI DAVO CHORALARI.

Sadirova Shakhlo Sobirovna, Ibadullaeva Nargiz Sapievna,

Khikmatullaeva Aziza Saydullaevna

LEVEL OF POPULATION IMMUNITY TO SARS-COV-2 IN THE REPUBLIC OF

UZBEKISTAN

Yusupov J.K., Abdullajanov B.R., Babadjhanov A.X.

COMPARATIVE MICROBIOLOGICAL EVALUATION OF THE EFFECTIVENESS OF

CHEMO-PHOTODYNAMIC THERAPY OF LONG-TERM NON-HEALING PURULENT

WOUNDS OF SOFT TISSUES

Ziyotova Malika Mashrabovna

DEVELOPMENT OF SPEECH IN CHILDREN WITH HEARING DISABILITIES

Zufarova Sh.A., Mirzaabdullahozhieva O.U., Yuldasheva O.S.

DIFFERENTIATED THERAPY OF CHRONIC HEPATITIS B AND C IN PREGNANT

WOMEN. 


\section{PEDAGOGICAL SCIENCES}

Allanazarova Mamura

METHODS OF TEACHING ENGLISH LANGUAGE VOCABULARY TO THE UZBEK

STUDENTS

Egamberdieva Aziza Mustafaevna

SOCIAL ISSUES OF ACTIVE CIVIC POSITION AND INITIATIVE DEVELOPMENT IN YOUTH.

Ergasheva Matluba Sabirovna

EFFECTIVE READING STRATEGIES FOR INCREASING THE READING

COMPREHENSION LEVEL OF FOURTH-GRADE STUDENTS.

I.X.Qutlimurodov.

PHYSICAL TRAINING OF ASSISTANT REFEREES ON FOOTBALL INCREASE

Khaydarov Sulaymon Amirkulovich

THE ROLE OF THE USE OF FINE ARTS IN TEACHING THE HISTORY OF THE

COUNTRY...

Khudoykulova Dilnoza Zafarovna

IMPROVING VOCABULARY USING EFFECTIVE LANGUAGE LEARNING

STRATEGIES.

Kodirova Khamida

CONTENT AND SIGNIFICANCE OF “OPTICS” DEPARTMENT IN GENERAL

SECONDARY EDUCATION PHYSICS

Madaminova Nilufar Madrasulovna

USING THE METHOD OF COLORIFMICS IN TEACHING ENGLISH IN PRIMARY

CLASSES

Tilavov Akbar

METHODS OF RESEARCH IN THE THEORY AND METHODOLOGY OF PHYSICAL

EDUCATION

Khakimova Sadoqat Dilshodbekovna

THE PROBLEM BEAHAVIOURS AND WHAT TO DO ABOUT IT?

\section{PHILOLOGICAL SCIENCES}

Otabekhoja Sobitov,

PERSONAL THEORY AND INDIVIDUAL CHARACTERISTICS

\section{STATE AND LAW}

Guzal Uzakova Sharipovna

THE ROLE OF LEGISLATION IN ENSURING THE SUSTAINABLE

DEVELOPMENT OF CITIES

Nodirov Muzaffar

SOME PROCEDURAL ISSUES OF THE INVESTIGATIVE ACTIONS AGAINST JUVENILE

SUSPECTS AND ACCUSED

Raximova IImira Marksovna, Artikova Ugiljon Umid kizi, Baxtiyarov Jumaniyoz Ixtiyor ugli

THE CONSTITUTION IS A GUARANTEE OF HUMAN RIGHTS AND FREEDOMS.

Rukhshona Madalieva Hakimdzhanovna

SOME ASPECTS OF UZBEKISTAN'S APPROACHES TO ENSURING FOOD SECURITY IN

THE CONTEXT OF COUNTERING THE COVID-19 CRISIS. 


\section{TECHNOLOGICAL SCIENCES}

Parahat Mailievna Matyakubova, Nuriddin Anvarovich Abdujabarov, Mirolim Muhammad o'g'li Mahmudjonov, Gulomjon Ibodullaevich Avazov INTERNATIONAL EXPERIENCE IN TECHNICAL REGULATION AND PRODUCT SAFETY.

\section{CULTUROLOGY}

Stukalenko Z. M.

PROBLEMS FOR THE APPLICATION OF INTERACTIVE LEARNING IN MUSIC ART LESSONS IN PRIMARY SCHOOL

\section{ECONIMICS SCIENCES}

Tetiana Marusei

USE OF CRM-SYSTEMS IN ENTERPRISE ACTIVITIES TOURIST INDUSTRY .71 


\title{
AGRICULTURAL SCIENCES
}

\section{FACTORS TO INCREASE THE EFFICIENCY OF THE MARKET OF MODERN SERVICES IN THE AGRO-INDUSTRY.}

\author{
Ruziev Hamrokul Jurayevich \\ (independent researcher of the Karshi branch of \\ TUIT named after Mohammed al-Khorezmi)
}

\begin{abstract}
The article discusses the main purpose of the agro-industrial complex, the system of cultivation, collection, processing and delivery of agricultural products to consumers, as well as the work being done to ensure sustainable labor, strengthen the country's economy and improve living standards.
\end{abstract}

Keywords: Agro-industrial complex, agricultural products, services, means of production.

The Action Strategy for five priority areas of development of the Republic of Uzbekistan for 20172021, adopted for the further development of the country, states: based on deep processing of raw materials.

In particular, the strategy of actions in five priority areas of development of Uzbekistan for 20172021. The accelerated development of the service sector, an increase in the role and share of services in GDP, radical changes in the structure of services, primarily due to modern high-tech services, require the correct and accurate organization of management accounting in the service sector as priorities for economic development and liberalization.

The scale and dynamics of development of the service sector in the agro-industrial complex, its role in agriculture are priorities for the scientific community in the field of economic research in the service sector. This situation did not fully encompass the aforementioned trends as well as modern economic research on knowledge of a particular product called a service. However, in the last decade, considerable attention has been paid to the study of the features of economic relations in the sphere of production and services.

The economies of the service sector and the agricultural sector complement each other. The service sector is one of the most important sectors of agriculture and has a significant impact on socio-economic activities. In this regard, service activities also play an important role in the material support of the agro-industrial complex. Expansion and development of the service sector in the agroindustrial complex will contribute to sustainable economic growth and increase the competitiveness of the national economy.

One of the main reasons for the low efficiency of the agricultural sector is the low quality of education, consulting and training services in the industry. Modern agriculture requires from producers and the entire agro-industrial complex a wide range of knowledge and skills to use modern machinery and equipment in open fields and in greenhouses until the minimum standards of hygiene and safety are met at all stages of production of harvesting technologies, processing and marketing. The lack of an effective agricultural knowledge and information dissemination system, including the provision of research, education and information advisory services, remains one of the biggest obstacles to the development of the sector.

For the modern service market, this is important not only taking into account the growing trend, but also taking into account the rapid development of material production and the constantly expanding diversification of services. Dozens of new services in the field of computer information technology and telecommunications have emerged over the past decade. In general, science-based services are gaining a significant share of the service market through specialized economic, technical, engineering 
and other similar knowledge. In our opinion, the following innovative groups will be typical for the service sector:

- Innovations in the field of technologies for the provision of modern services in the agricultural sector, the introduction of new technological equipment, which significantly expands the range of services provided (telecommunications, mobile communications, e-commerce, etc.);

- Increasing the consumer value of services in the agro-industrial complex, improving the quality of services provided (innovative services in education, healthcare and services that play the role of social infrastructure, characterized by massive demand from the population);

- Improvement of business processes in agriculture (strategic planning, outsourcing, co-working, etc.). Implementation of new management methods based on the use of new information and communication resources in the service sector (ISO quality management, CRM customer management, ERP management resources, etc.));

- Improving institutional conditions for the activity of the sphere of services in the agricultural sector (creation of legislative and normative bases, development of infrastructure in the sphere of services, realization of educational programs, etc.);

- Increasing the competitiveness of enterprises in the agro-industrial complex, directed at improving the business environment in the agricultural sector and increasing the quality of rural life (diversification of business processes, increasing the volume of services, etc.).

- Introduction of mechanisms to increase investment privacy services in agriculture (improvement of investment and tax legislation, creation of special zones, development of infrastructure and dr.). Creation of new financial instruments, private financial instruments, and private financial partnerships tendency.

A rapidly developing competitive agro-industrial complex is the basis of the country's food security. It is obvious that ensuring such development and achieving competitiveness is possible only through the effective use of production factors. In the scientific literature, the word factor is interpreted as one of the sources of production activities of an enterprise and the economy as a whole. It is the driving force behind economic and production processes, influencing the results of their activities.

Considering that $71 \%$ of agricultural products are produced in the non-state sector of the agrarian economy, in addition to these factors, service factors are unlikely to increase the efficiency of economic activity of economic entities. These include services for the cultivation of crops, the development of innovative technologies for crop and livestock production, a set of measures to increase the value of their products, the assessment of the movement of goods and much more.

Description of factors affecting production efficiency.

\begin{tabular}{|c|c|c|c|}
\hline & \multicolumn{2}{|c|}{ Production of products. } \\
\hline & & $\begin{array}{c}\text { Dekhkan farms } \\
\text { (private leased } \\
\text { farms). }\end{array}$ & Farms. \\
\hline 1. & By the level of production development. & $\begin{array}{l}\text { Traditional scientific } \\
\text { work }\end{array}$ & $\begin{array}{l}\text { Manufacturing products } \\
\text { using high technologies }\end{array}$ \\
\hline 2. & $\begin{array}{l}\text { By the level of application of types of } \\
\text { services. }\end{array}$ & Partially used & Fully used \\
\hline 3. & Use of production products. & $\begin{array}{c}\text { Partially and } \\
\text { naturally in brand } \\
\text { form }\end{array}$ & As a brand \\
\hline 4. & About channels of realization. & $\begin{array}{l}\text { From home to } \\
\text { market }\end{array}$ & $\begin{array}{l}\text { With the farm, on the } \\
\text { market, organization of } \\
\text { reproduction }\end{array}$ \\
\hline 5. & Product pricing. & $\begin{array}{l}\text { According to market } \\
\text { supply and demand }\end{array}$ & $\begin{array}{l}\text { Exclusion of products } \\
\text { at the expense of a state } \\
\text { organization }\end{array}$ \\
\hline 6. & Distribution of income. & $\begin{array}{l}\text { Distribution among } \\
\text { family members }\end{array}$ & $\begin{array}{l}\text { For physical labor and } \\
\text { intellectual share }\end{array}$ \\
\hline
\end{tabular}


Analyzing the list of factors presented in the table that affect the production efficiency of agriculture, we can conclude that the farm uses high-tech technologies in the production of agricultural products.

At the same time, competition intensifies the conflict of economic interests, sharply increases differential economic costs, and stimulates the creation of monopolies. Competition is a factor between business entities in achieving the best results in their own interests. Consequently, there is competition in the agro-industrial complex, which creates competition between economic entities to protect their interests. In the process of competition, each agricultural producer seeks to create the most favorable conditions for obtaining benefits and agricultural products at the expense of the rest of the market exchange.

\section{Literature}

1.Тураев Б.Х., Рузиев Х.Ж. ИЗУЧЕНИЕ ПРОБЛЕМ ФУНКЦИОНИРОВАНИЯ АПК С ИСПОЛЬЗОВАНИЕМ ТЕОРИИ АГРОПРОМЫШЛЕННОЙ ИНТЕГРАЦИИ. ФеНОМЕН рыночного хозяйства: от истоков до наших дней. Партнерство в условиях риска и неопределенности: сб. науч. трудов. VIII междунар. науч.-практ. конф. по экономике (Самарканд-Карши, 1-5 апреля 2020 г.)

2.РУЗИЕВ Х.Ж. Инвестиционный потенциал как основа развития АПК регионов. Финансовоправовые и инновационные аспекты инвестирования экономики региона. Материалы научнопрактической конференции. - Фергана: ФерГУ, 2020. - 362 стр. 


\title{
HISTORICAL SCIENCES
}

\section{THEORETICAL AND METHODOLOGICAL ASPECTS OF STUDYING THE HISTORY OF CENTRAL ASIA, ESPECIALLY, UZBEKISTAN}

\author{
Doctor of Political Sciences K.A.Yunusov \\ Professor of Andijan State University named \\ after Zahiriddin Muhammad Babur \\ kamoyunus@mail.ru \\ telephone, telegram: +998905493492
}

Each science has its own scientific concepts, methods, methodology and theoretical and methodological bases. In particular, the history of Uzbekistan, along with other social sciences and humanities, has its own methods, methodologies and theoretical and methodological bases. The study of the history of Uzbekistan, its important events requires scientific research based on clear scientific and theoretical concepts, teachings and methodology.

Human civilization, a particular people, nation and state, has gone through unique historical stages during its historical development. They are distinguished by distinctive socio-economic, political, legal features, tendencies, laws. These laws are called the laws of history.

The socio-historical development of any state is under the significant influence of certain objective and subjective factors. The historical development of Central Asia, in particular Uzbekistan, and the prospects for its further development have been influenced by certain objective and subjective factors. It is very important to study these factors within the framework of the philosophy of history.

The significant impact of the natural environment on human history operates in the form of a specific law. In the most ancient times, the role of rivers in human life, in their lives, was incomparably great

Historically, the peoples living along the rivers have been engaged in irrigated agriculture, forcing them to live in a certain area in an organized manner, to enter into social relations on the basis of mutual understanding. As a result, the foundations of statehood were laid. The countries of the most ancient countries (Ancient Egypt, Babylon, Greece, Rome, India, China, Khorezm, Bactria, Sogdia) can serve as an example of our opinion.

This period can be called the period of "River civilization". The period of "River civilization" in the history of mankind lasted from 6-5 thousand years BC to the end of the XV century AD. Both the oldest states in Central Asia, in particular in Uzbekistan, and the centralized state founded by our great-grandfather Amir Temur are part of the "River Civilization". During this period, the sociopolitical and cultural life of Central Asia flourished and gained a unique reputation at the international level. The fact that the Great Silk Road, which connects East and West economically, crosses the borders of my homeland has also had a positive impact on socio-economic development.

The historical period in the history of mankind, conventionally called the "Sea and Civilization" - lasted from the end of the XV century to the end of the XIX century, in which the role of the sea in the life of nations is characterized by a tremendous increase.

Socio-economic ties between the littoral states have been further strengthened through trade, leading to their comprehensive development. Far from the sea, the countries of Central Asia (such as Khiva Khanate, Bukhara Emirate, Kokand Khanate) during this period were depressed and lagged far behind socio-economically. During the "Sea and Civilization", land trade routes, in particular, the "Great Silk Road" also completely lost their former status.

The period of "Sea civilization" had a great impact on the socio-economic development of the countries it covered, and even today, trade, tourism and other relations by sea have not lost their importance. 
The countries that were part of the "Ocean civilization", which began in the late XIX century, have had a significant impact on the socio-economic development of peoples. "Ocean civilization" still plays a significant role in human development and determines the fate of nations. Even at the beginning of the last century, the peoples of the world, who were very backward and had almost no natural resources, still lead the world in politics and economy.

The desolate islands, which are part of the "Ocean Civilization" and are located on the trade routes in the oceans, today have high cultural and tourism centers, equipped with the latest technology, highly organized production and living standards, quality of life. The rise in the development of the Pacific, the Atlantic, the Indian Ocean, a number of countries in the Indo-Chinese region, the islands of many is a shining example of this.

Based on the above considerations and considerations, we can say that the peoples of Central Asia, who were not part of the maritime and oceanic civilizations, experienced their period of depression from the end of the 15th century to the end of the 20th century. As a result, they lived in subjection to other nations.

During the Soviet era, Uzbekistan was a centralized republic, a supplier of raw materials to the center, but through the existing economic, trade and communication systems, it was part of the "Sea Civilization" and the "Ocean Civilization".

After the collapse of the Soviet Union, Uzbekistan has gone through a difficult socio-economic period for the past 29 years since gaining its national independence. Its complexity is that it seeks socioeconomic development without being part of the "Sea Civilization" and the "Ocean Civilization".

From the above opinions and comments, it can be concluded that the substantiation of theoretical and methodological aspects of the history of Uzbekistan should be based on the objective laws of human history. 


\title{
THE ROLE OF THE KUSHAN EMPIRE IN WORLD CIVILIZATION
}

\author{
Tashmuradova Sarvinoz Quvondiq qizi \\ Student of the Denau Institute of Entrepreneurship and Pedagogy \\ email:toshmuradavasarvinoz@gmail.com \\ Bengmatov Alibek Kahramon oglu \\ Student of the Denau Institute of Entrepreneurship and Pedagogy
}

\begin{abstract}
Annotation: This article details the sources and assumptions of scholars about the origins of the Kushan Empire, as well as the founding of the state, the archeological monuments of that period, their culture, way of life, and their contribution to world civilization.

Keywords: Kushan, Xiumi Guishuang, Shuangmi, Hidun, and Dumi Takht-i Sangin, Surkh Kotal, Tokhars
\end{abstract}

Introduction: We all know there are so many countries in the world. They also have a place on the world map. But centuries ago, they were replaced by completely different countries. These laid the groundwork for their survival to this day. One such historical state is the Kushan Empire. Emerging in South Asia, this empire has a place in world civilization.

History of origin. The term "Kushan" or arrangement pertaining to a dynasty or ability was first used on coins minted by King Geray, who ruled from the end of the 1st century BC - beginning of the 1st century AD. The territory of the Kushans' commercial property included Northern Bactria (southern Tajikistan and southern Uzbekistan, southeastern Turkmenistan). There is a scientific agreement that the Yueji are people of Indo-European descent. The origin of the Yueji is precisely Tokhari.[1]

Originally Iranian, especially saka is also somewhat popular among scholars. Others believe that the Yuezhi were originally a nomadic Iranian people, who were later partially assimilated by the Tokhars they migrated to, including elements of both Iran and Tokharia. The Yueji are described in the writings of the Great Historian and in the Han Book as living in eastern Xinjiang and northwestern Gansu, in northwestern present-day China, until they were beheaded by their king, Hyunnu (ed). They also fought wars with China, forcing them to move west in 176-160 BC.[2]

The five tribes that make up the Yueji are known in Chinese history as the Xiumi Guishuang, Shuangmi, Hidun, and Dumi.In the II-I centuries BC there are some traces of the existence of the Kushans in Bactria and Sogdiana, who moved the Saks far from the south. Archaeological structures include Takht-i Sangin, Surkh Kotal (monumental temple) and Known in the Carpet Palace. It is known that the Kushans built castles in the ruins of ancient Hellenistic cities such as Ay-Hanum. Various sculptures and friezes from this period are known, such as those used by archers on horseback, and especially by people like the Kushan prince of Halchayan, who had an artificially deformed skull, a practice well-established in nomadic Central Asia. Halchayan thinks that some of the sculptural scenes depict Kushans fighting the Saks. In these images, the yueji are depicted with glorious demeanor, the beards are usually depicted with sides and more or less grotesque facial expressions.[3]

Kadfiz I, who first ruled the country with the title of Jabgu, later founded the Kushan Kingdom, during which the Kushans conquered much of present-day Afghanistan and Pakistan. During the reign of Vima Kadfiz, the successor of Gaddafi I, most of India was annexed to the Kushan kingdom. The heyday of the Kushan kingdom dates back to the reign of Kanishka. Pants of Kushan property in Central Asia. The border is along the Gissar ridge, and in the mountain gorges there are very strong boundary walls.[4]

During the Kushan Empire, the number of prisoners of war increased as a result of frequent wars. The Kushan Empire, which was at war with China and Parthia, was an ally of Rome, which was at war with Parthia for dominance in the Middle East. But trade interests have brought these countries closer together. Favorable conditions have been created for the development of international trade along the Great Silk Road. In the east - through the oases of the annexed cities of East Turkestan with China, in the south - with the Kushans in northern India, in the west - by sea, through Egypt or by land through Iran to the cities of the Roman Empire in the Mediterranean, in the north through Khorezm and the Urals. traded with. More than a hundred urban and rural ruins of the Kushan period have been identified in southern Uzbekistan. During this period, the city and the countryside were closely intertwined: there were many small villages around each cityThe Kushan kingdom was a state where political power was in the hands of the clergy, in which the king was not only a secular 
leader but also a high priest. The state was divided into satrapies (see Satrapia), and their satrapies had some freedoms. Although the Kushan kingdom was a state of slavery, the rural community played an important role in it. The Kushan kings pursued a wide-ranging policy of interfaith reconciliation in the country: the population was predominantly Mahayana Buddhism, and there were many other religions in the country, such as Zoroastrianism, Zoroastrianism, and Hinduism. Crafts, domestic and foreign trade are widely developed. The monetary system used more gold and copper coins. Agriculture, especially irrigated agriculture, was developed, and most types of agricultural crops were planted. The Kushan kingdom was abolished in the first half or middle of the 3rd century AD. Baghdad-Tokharistan was part of the Sassanid state as private property. It was ruled by representatives of the Sassanid dynasty with the title of Kushan.[5]

The Kushan Empire was one of the most powerful kingdoms in the Ancient East, competing in all respects with Rome, Parthia, and China, and for two centuries had a profound influence on the political, economic, social, and cultural life of Asians. The unification of several countries, peoples, and nations within a single kingdom brought different cultures closer together, and the cultures of the time brought together the cultures of Bactria, Greece, Sak, and India. However, some aspects of the history of the culture of the Kushan kingdom are still very vague, and historians, orientalists, and archaeologists are conducting consistent and in-depth research to shed light on them. For example, international symposiums were held in London in 1913 and 1960, in Dushanbe in 1968, and in Kabul in 1970, and the UNESCO Commission for the Study of the History and Culture of Central Asia made the study of Kushan history and culture one of its main tasks.[6]

List of used literature

1.Kushan kingdom // BRE. T.16. M., 2010.

2.Andronovo culture // BRE. Vol. 1. M., 2005.

3.Massageta // BRE. T.19. M., 2011.

4. Turchin, Peter; Adams, Jonathan M.; Hall, Thomas D (December 2006). "East-West Orientation of Historical Empires".

5.The Dynasty Arts of the Kushans, University of California Press, 1967, p.7

6.Bahodir Turgunov, Temur Giyosov. O'zME. The first volume. Tashkent, 2000 


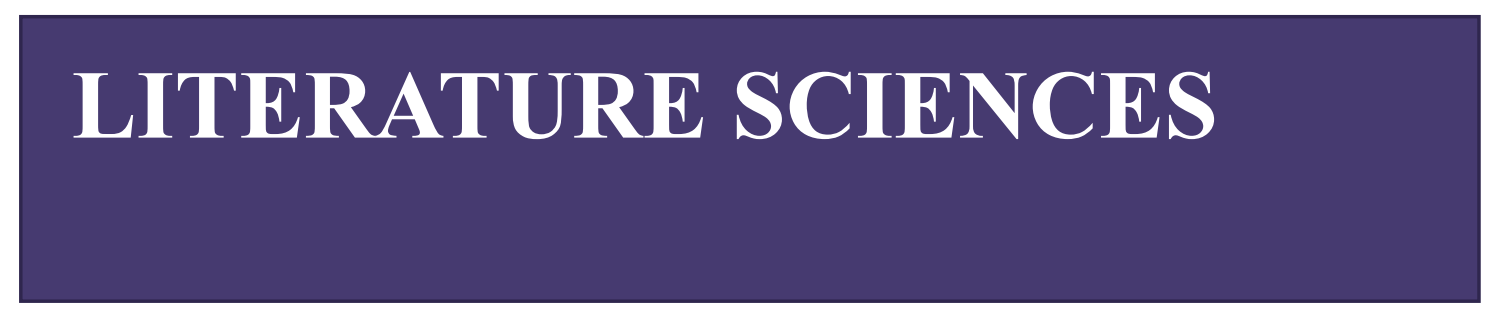

\title{
AGAHI - IS ONE MEMBER OF THE UZBEK CLASSIC LITERATURE
}

\author{
Khudaybergenova Khosiyat Kahramonovna, \\ Matyakubova Nazira Azatovna, \\ Rakhimova Dilafruz Akhmedovna \\ Khorezm regional Urgench district School № 14 \\ The teachers of mother tongue and literature.
}

Annotation: The article talks about the great historian and poet of the Uzbek people and their historical chronicles. Information is given on manuscript lists, the structure and scientific significance of his works in the study of the history of the peoples of Central Asia.

Agahi is not only a great figure in the literary movement, but also a great historian. His real name is Muhammad Riza-mirab bin Erniyazbek, who was nicknamed born in December 1809. In Khiva . His father was Erniyazbek, the younger brother of Munis . After the death of Munis, Agahi was appointed by Allakulikhan instead of his uncle to the post of mirab. He was not only the successor of Munis in the khan's service, but also his student. It is very important to study and disseminate the historical works of Agahi now, when our history is

reviving thanks to independence. This is a rare, reliable source of information about the history of the formation and development of Uzbek statehood over three millennia, in particular, the history of our country in the first half of the 19th century. From this point of view, an important task of our historians is to prepare and publish the scientific text of the historical works of Agahi . From the age of 20, Agahi began his career as a statesman in the palace of the Khan. He lived and

conducted his creative activity at a time when 8 khans came to the throne in Khiva Muhammad Rakhimkhan I (1806-1825), Allakulikhan (1825-1843), Rakhimkulikhan (18431845), Muhammadaminhan ( 1845 - 1855), Abdullahan (1855), Kutlugmuradhan (1855), Said Muhammedkhan (1856 - 1864) and Muhammad Rakhimkhan Feruz .

Agahi wrote 19 poetic stories, 17 of them in Persian. These include the "Historical death of Allakulikhan and Zhulus Rakhimkulikhan ", "The History of Zhulus Muhammedaminhan ", "Historical Julius Said Muhammedhana ", " Istrian Madrasah of Muhammedhana ", "Historical Madrasah of Muhammadaminhan " and others. These poetic stories with literary monuments have historical significance. Because they contain many historical dates. With the help of the stories of Agahi, refinements are now being made to many historical dates.

Agahi, as a creative historian, completed the unfinished Munis historical chronicle " Firdavs ul ikbol ", reflecting in it an event of the period from 1812 to 1825 . "Firdavs - ulikbol " includes events from the earliest times of Khorezm during the reign of Muhammad Rakhimkhan I (18061825). "Reese ud-dawla ", "State affairs." It describes the events that occurred during the reign of Allakulikhan . The information provided by Agahi on the interpretation of the popular strike led by Aydust in 1827, 1828 is especially valuable.

"Zubdat ut-tavorikh", "Cream of stories". This work highlights the historical events of the reign of Rakhimkulikhan in Khorezm . It consists of two parts. From the birth of Rakhimkulikhan to the throne of the khan, events are described in the first part, and in the second - events that occurred from the khanate to his death. In the works "Zhami - ul - vakeati -sultan", "On the events of the Sultans" the historical events of the reign of Muhammadaminhan (1846-1855) in Khorezm are described. The "Gulshani State" of Agahi devotes to the rule of Saidmuhammedkhan (1856-1865), which describes in detail the popular movement of 1855-1856, a letter about the help of Uzbek and Turkmen tribesmen 
to the Russian authorities, as well as riots and famine in the country. Chronicle "Shahid-i Iqbal" - the last work of Agahi on the history of Khorezm. The reign of

Muhammad Rahimkhan Feruz is the essence of the work. The only copy of this work is stored in the Manuscript Department of the Institute of Oriental Manuscripts of the Russian Academy of Sciences. Here Agahi describes the history of the emergence of Mohamed Rahim Khan II in Khiva, a feast and a feast of honor to complete the construction, beneficence He translated a lot of historical works. Of these, in the works "Bados ul-vakos", "Anvori Sukhaili", "Haft Kishvar", "Akhloki Mukhsiniy", "Zubdat ul Hikoyat", "Kobusnoma" expresses questions of justice, ruler and citizens, ruler and wards, ruler and army the identification and punishment of tyrants, as well as the eradication of tyranny and immorality. In his historical works, Agahi provides valuable information on the economic situation of thekhanate, agricultural and irrigation systems, communications and transport, on urban planning and crafts, science and culture, state and political figures, geography and ethnography. Therefore, the historical and spiritual significance of these priceless works is enormous. With these works, he created a valuable historical chronicle of Khorezm, which dates back more than half a century and has made a significant contribution to the development of historical science in Central Asia. His historical works were highly appreciated by such great historians as orientalists such as V.V. Bartold, P.P. Ivanov, A. Yu. Yakubovsky, S.P. Tolstov, Ya. G. Gulamov and K. Munirov. We are well aware that Agahi lived and conducted his activities under the rule of all 8 rulers, he took part in the military campaigns of the khan, saw all the events with his own eyes, and then truthfully wrote about them in his historical works. The writer's historical works are examples of a literary publication. Each historical event is presented in the literary style of various forms and genres. Agahi was primarily a poet and sought to convey the events of the era of the reign of different khans in an artistic form, both prosaic and poetic. In his work, we find such lyrical genres as Masnavi, Rubai, gazelles, Kyt, Nazm, Tari, with a total volume of 1045 bytes. Poems in the

historical works of the poet also require a separate study, which is largely ignored by researchers. "Shahid ul Iqbal" -masnawi: A magnificent building, given by God, Let it stand eternal and unharmed; May science flourish in it, May its cloisters rejoice; Beautifully inside and out, Every stone is as diverse as the rays of the sun;

If anyone wants to glorify him, let him come and see him; If anyone wants to see what is inside him, Togo's mind will numb with surprise; Almost all of the historical works of Agah contain valuable information not only about the Uzbek

people, but also about the Turkmens, Karakalpaks, Kazakhs and other ethnic groups living in Khorezm. Especially the situation of the Turkmen and Karakalpak peoples, and their socio-cultural situations, various movements of peoples and strikes are described objectively and conscientiously. This suggests that Agahi acted very wisely. In particular, the campaign of the Karakalpaks against the oppression of the Khiva khanates under the leadership of Aydustbiy in its original form.

\section{References}

1.V. Abdullaev "History of Uzbek literature" 2- volume. T: 1980

2.Agahi "Works". 1, 2 volumes. T: 1872

3.K. Munirov "Historiography in Khorezm" (beginning of the 7th -19 th -20 th centuries) T: Literature and art. 2002 


\title{
MEDICAL SCIENCES
}

\section{ANALYSIS OF CLINICAL MANIFESTATIONS OF COVID-19}

\author{
Abdukadirova M.A., Khikmatullaeva A.S., Jumanov B.A. \\ Scientific Research Institute of Virology, \\ Ministry of Health of the Republic of Uzbekistan
}

Relevance. COVID-19 is an acute respiratory infection caused by the SARS-CoV-2 coronavirus, which can occur both in the form of an acute respiratory viral infection of the mild course and in a severe form. The most common complication of the disease is viral pneumonia, which can lead to acute respiratory distress syndrome and subsequent acute respiratory failure, in which oxygen therapy and respiratory support are most often required. In the majority of those infected, the infection is mild or asymptomatic (Glybochko P.V. et al, 2020). In about 15\% of cases, the disease is severe with the need for oxygen therapy, and in $5 \%$ of cases, the condition of the patients is critical (World Health Organization, 2020). Symptoms of the disease include fever, fatigue and dry cough, loss of taste or smell, body aches, sore throat, diarrhea, conjunctivitis, headache, and skin rash. Dangerous symptoms that require medical attention are shortness of breath or shortness of breath, chest pain or chest tightness. According to the studies of Carlos del Rio et al, all patients admitted to the hospital had pneumonia with infiltrates radiographically detected (Carlos del Rio et al, 2020). Moreover, pneumonia can be detected in asymptomatic cases of infection (Huang C. et al., 2020). In the majority of those infected, the infection is mild or asymptomatic (Glybochko P.V. et al, 2020). In about 15\% of cases, the disease is severe with the need for oxygen therapy, and in $5 \%$ of cases, the condition of the patients is critical (Carlos del Rio et al, 2020).

The aim of the study was to determine the clinical manifestations of moderate forms of COVID-19.

Materials and methods: a retrospective analysis of 80 case histories of patients with COVID-19 who received inpatient treatment at the clinic of the Research Institute of Virology of the Ministry of Health of the Republic of Uzbekistan was carried out. Patients were mainly with a moderate form of the disease, since at the time of the study, patients with mild severity were treated on an outpatient basis at home, and patients with severe forms were in the intensive care unit. Of the 80 people, there were 46 men $(57.5 \%), 34$ women $(42.5 \%)$ aged 20 to 71 years (the average age was $41 \pm 2.3$ years). Patients were admitted to the hospital on average $4.6 \pm 0.9$ days of illness. The diagnosis of COVID-19 was confirmed by PCR with hybridization-fluorescence detection using a set of reagents "Vector-PCRRV-2019-nCoV-RG" (Russia, Novosibirsk).

Research results. The most frequent clinical manifestations of the disease were weakness $(85.0 \%)$, cough $(68.8 \%)$, sore throat $(41.3 \%)$, fever $(41.2 \%)$, sore throat $(25.0 \%))$, headache $(18.8 \%)$, anosmia (loss of smell) $(11.2 \%)$, agenesis (loss of taste) (12.5\%), diarrhea (10.0\%). In $26(32.5 \%)$ patients, the disease proceeded with lung damage (pneumonia), which was observed in age groups over 30 years old. The incidence of pneumonia was similar in men and women.

When examining patients with pneumonia, weakness occurred in $84.6 \%$ of cases, hyperthermia in $61.5 \%$, cough in $9.2 \%$, anosmia in $34.6 \%$ and agenesis in $38.4 \%$, sore throat in $34.6 \%$ and sore throat in $30.7 \%$ of cases. Dyspnea was 2.6 times more common in patients with pneumonia $(30.7 \%)$ than in patients without pneumonia (5.5\%), although the difference was not significant. Symptoms such as chills and fever $(\mathrm{P}<0.05)$ also had significant differences.

\section{Conclusion:}

1. COVID-19 has a variety of clinical manifestations.

2. The most common symptoms of COVID-19 are weakness, cough, headache, sore throat, fever. 3 . Patients with COVID-19 with pneumonia had symptoms that are rare in other respiratory infections, these are agenesis $(38.4 \%)$ and anosmia $(34.6 \%)$.

4. With pneumonia in patients with COVID-19, the clinical picture did not always coincide with the data of chest x-ray. 


\title{
ASSESSMENT OF THE ROLE OF HEARING AIDS IN REHABILITATION OF PATIENTS WITH THE SENSORINEURAL HEARING LOSS
}

\author{
Arifov S.S., Kalandarova D.A., Orifov S.S. \\ Tashkent Institute of Postgraduate Medical Education \\ Tashkent, Republic of Uzbekistan
}

The results of examination of 87 patients with sensorineural hearing loss aged 18 to 77 years are presented. The cause of sensorineural hearing loss was the acute respiratory viral infections, side effects of amino glycoside antibiotics, acute and chronic disorders of cerebral microcirculation against the background of diseases of the cardiovascular system, acoustic trauma. All patients underwent a comprehensive clinical and audiological examination. The patients were divided into two groups. 75 patients of the first group underwent rehabilitation using the hearing aids, the remaining 12 patients of the second group did not use hearing aids.

Keywords: sensorineural hearing loss, hearing aids, rehabilitation.

Introduction. Hearing aids is a main method of rehabilitation for patients with sensorineural hearing loss (SNHL). Correct selection of the hearing aid makes it possible to compensate for hearing loss and improve the "quality" of life of patients.

Purpose. The aim of this study was to assess the role of using hearing aids in the complex rehabilitation of patients with SNHL.

Material and methods. There were examined 87 patients, aged from 18 to 77 years. All patients underwent a general examination, endoscopic examination of the ENT organs, acumetry, and pure tone audiometry. To determine the degree of hearing loss, was used the international classification of hearing impairment proposed by WHO (1997).

Hearing impairment was caused by acute respiratory viral infections, side effects of amino glycoside antibiotics, acute and chronic disorders of cerebral microcirculation against the background of diseases of the cardiovascular system, acoustic trauma.

The first degree of hearing loss was established in 7 patients. In 32 patients second, 40 patients third and 8 patients fourth degree of hearing loss, according to which were divided into two groups. The first group consisted of 75 patients. All of them were fitted with a hearing aid for the better hearing ear by non-linear amplification of sounds, and during the observation they regularly used hearing aids. The second group included the remaining 12 patients who, for various reasons, did not use hearing aids. Efficiency assessment was carried out using a questionnaire before and after using hearing aids for 3 months. The questionnaire included an assessment of the state of hearing, tinnitus and the study of cognitive functions. The control group consisted of 10 apparently healthy individuals.

Results. Before using hearing aids, all patients in both groups noted hearing impairment, impaired speech intelligibility, focused attention on a decrease in the pleasure of communicating with others, a feeling of loneliness and depression. In 62 patients of the first group, there was endogenous nonemission murmur, which in 47 cases was bilateral and 15 - unilateral. In the second group, 7 patients had unilateral endogenous non-emission murmur.

Patients of the first group, from the beginning of using the hearing aid, noted an improvement in hearing and an improvement in speech intelligibility. The results of perception of whispering and speaking with a hearing aid on the side of hearing aid did not differ from those of healthy individuals. During the use of the hearing aid in four cases, endogenous non-emission noise was not felt, and in three cases, its intensity significantly decreased compared to the initial state. No noise occurred when the hearing aid was fitted to the ear with noise.

On the 4th week of observation, five patients had moderate manifestations of a decrease in the pleasure of communicating with others, a feeling of loneliness and depression. By the end of the observation, only one patient had individual manifestations of a decrease in the pleasure of communicating with others.

By the end of the observation, the indicators characterizing cognitive functions in patients in the main group did not differ from those in the control group. In the comparison group, the difference between the initial and final results of the questionnaire was not observed. 
Thus, using adequate fitted hearing aids contributes to a pronounced improvement in the "quality" of life and cognitive functions of patients with SNHL. This dictates a wider use of hearing aids as an effective method of hearing rehabilitation in this category of patients.

References.

1.Byrne D, Dillon H, Ching T et al. NAL-NL1 Procedure for Fitting Non-linear Hearing Aids: Characteristics and Comparisons with Other Procedures. // Scandinavian Audiology J. - 2007. - Vol. 12. - P.37-51

2.Eva Joanovič, Helena Kisvetrová, Dagmar Nemček et al. Gender differences in improvement of older-person-specific quality of life after hearing-aid fitting // Disability and Health J. - 2019 - Vol. 12(2) - P.209-213.

3.Katz J. Handbook of Clinical Audiology // Williams\&Wilkins, 1994. 839p

4.Thomas M, Schönweiler R, Löhler J. Comparison of different measurements of the benefit in hearing aid fitting using the APHAB // Laryngorhinootologie. - 2020 - Vol. 99(8) - P.536-544.

5.Yamada Y, Švejdíková B, Kisvetrová H. Improvement of older-person-specific QOL after hearing aid fitting and its relation to social interaction // Journal of Communication Disorders - 2017 - Vol. 67 - P.14-21. 


\section{RESTORATION OF POSTOPERATIVE JAW BONE DEFECTS USING OSTEOMATERIALS, PLATELET-RICH PLASMA}

Ikramov G.A., Yuldashev A.A., Mardonova N.P., Olimjonova G.G. Tashkent State Dental Institute, Uzbekistan

Key words: osteoconductive and osteoinductive, platelet-rich plasma, odontogenic cysts, fibrin, osteogenesis.

Annotation: One of the urgent problems in surgical dentistry is the search for the most effective materials and methods for optimizing physiological and reparative osteogenesis in order to ensure the fastest and complete restoration of damaged structures in the area of bone defects of the jaws formed during surgical interventions on the alveolar process of the upper and alveolar parts of the lower jaws as a result of extraction of teeth, including impacted and dystopic ones, during cystectomy of odontogenic cysts, dental implantation, during operations on directed bone tissue regeneration.

Currently, in surgical dentistry, to restore the integrity and shape of the alveolar process of the upper jaw and the alveolar part of the lower jaw, autogenous, allogeneic and xenogenic grafts (Chitosan, Allomatrix-implant, Biomatrix-implant, Bio-Oss Collagen "," OsteoGraft N "," BioGen "," PepGen “,” Endo-gen "," OsteoBiol “," Gen-Os "," Apatos “,” Bioteck osteoplant "and others), artificially synthesized mineral components bone matrix - hydroxyapatite (HAP) and tricalcium phosphate (TCP) in various forms, combinations (Osteograft LG, Calcitte, Durapatite, Algipor, Vitcolit, Ceramit, Cerosorb Easy-graft "," Bioresorb "," GAP-99G -granules ", etc.) or in the form of their composition with proteins (collagen), sulfated glycosaminoglycans (" Keratan "," Bioimplant ", etc.), as well as in combination with chemical compounds - sulfates ("Haspet") or calcium phosphates (Grigorian AC 1996; Ivanov S.Yu. et al. 1999; Ivanov S.Yu., Panin AM ... 2002; A.I. Grudyanov et al. 2003; Panin A.M., Ivanov S.Yu., Kuznetsov G.V. 2003; Panin A.M. 2004; Grigorian A.C., Toporkova A.K. 2007; Collins J.A. 1999; Deeb E.M. 1999; Ferraro J.W. 1999 and others). In recent years, ultradispersed and nanostructured forms of HAP and TCP ("Ostim-YuO", "Medkam", "Nanobone", etc.) have become increasingly widespread.

The main task of developing compositions intended for the restoration of bone defects and cavities, according to most researchers, is the search for effective combinations of materials with both osteoconductive and osteoinductive properties. It should be recognized that this task is multifaceted and has not yet been fully resolved, as evidenced by the large number of solutions proposed by domestic and foreign authors.

During the entire existence of surgery, there is a constant search for means to improve the process of wound healing after surgery. It is known that the use of platelet-rich plasma from the patient's autologous blood can accelerate wound healing by 2-3 times using the body's own reserves (Bennett N.T., Schultz G.S., 1993; Marx R.E., Carlson E.R., et al., 1998).

Improvement of methods of therapy for inflammatory complications arising after surgical interventions and the creation of predictable regeneration of bone and soft tissues in the field of surgical intervention is an urgent problem in surgical dentistry.

In modern surgical and therapeutic dentistry, according to the data of Zoryan E.V., Larentsova L.I. (1998), Verigina GI (1998), Barer G.M., Zoryan E.V. (1999), Pesonina S.P. et al. (2004), Zoryan E.V. (2005), Olshanetskaya N.V. (2008), Pashkova K.A. (2008), Taitz B.S. (2000), Becker Werner (2005), homeopathic medicines are widely used, in particular "Traumeel S", which has a wide spectrum of pharmacological action and the ability to deeply penetrate and accumulate in bone tissue.

Considering the problem of the recovery stage of eliminating postoperative bone defects of the jaws as a whole, it should be recognized that the extensive arsenal of drugs available to specialists is still characterized by a rather limited spectrum of their action separately, which necessitates further search for optimal combinations of a multicomponent pathogenetically substantiated complex of therapeutic agents. possessing both osteoconductive, osteoinductive and anti-inflammatory characteristics. It can be assumed that the effective combination of components of mineral (HAP, TCP), autologous (biological) and plant origin, studied in the experiment and substantiated in the clinic, will make it possible to provide more optimal conditions for the course of regenerative processes in bone tissue, thereby reducing the process of restoring the body's homeostasis. the patient as a whole.

Based on the foregoing, the presented experimental-clinical study in this area of restorative 
medicine and surgical dentistry is relevant.

Purpose of the study. Optimize conditions for recovery of bone tissue of alveolar ridge of the maxilla and mandible alveolar part, acceleration of reparative osteogenesis and soft tissue regeneration after dental surgery.

Research objectives: To conduct a clinical and X-ray study of the effectiveness of experimentally substantiated fibrins, platelet-rich plasma for optimization of reparative osteogenesis of jaw bone defects in the study group and in the comparison group.

Research methods. Two groups of children with cysts of the lower jaw within the dentition were examined. I-group. The traditional group, in which the postoperative defect was filled with a blood clot after cystectomy (p-20), group II with the use of fibrin, platelet-rich plasma (p-20). All children underwent clinical, radiological and morphological examinations. Experimental and morphological study carried out by us on rabbits of the "Soviet chinchilla" breed

In the experiment, using morphological methods, the dynamics of reparative osteogenesis in the elimination of postoperative bone defects of the jaws using fibrin, platelet-rich plasma was studied. It has been established that the complex of tissue reactions is based on a reparative process without signs of toxic effect and immune conflict. In an experimental morphological study, the nature of differentiation and maturation of bone structures was determined, the rate and degree of bone tissue regeneration during wound healing under a blood clot was determined, with the separate use of fibrin, platelet-rich plasma. Morphologically and clinically substantiated the effectiveness of the separate and combined use of fibrin, autologous platelet-rich plasma (biological component). In the course of an experimental study on rabbits, the nature and timing of bone tissue regeneration were studied. In the experiment and in the clinic, it was found that the healing of a bone wound under a blood clot and when using osteomaterials and other osteoinductive agents differ in terms of healing time, in the course of the postoperative period and in the severity of inflammatory and pain reactions. It has been experimentally and clinically proven that different rates of resorption of osteomaterials by fibrins, platelet-rich plasma determine the choice of each material for filling bone defects, based on the size of the defect and various goals of postoperative rehabilitation. It was found that filling the bone defect with fibrins, platelet-rich plasma provides full reparative regeneration of bone tissue, reduces the risk of postoperative bleeding and reduces the number of inflammatory complications. Experimentally and clinically proven the effectiveness of fibrins, platelet-rich plasma is recommended for filling large post-extraction defects, in the treatment of various odontogenic cysts, operations for directed bone tissue regeneration. When using fibrins, platelet-rich plasma, the time of reparative osteogenesis, healing of soft tissues is significantly reduced, there is a decrease in postoperative complications, edema, and pain.

\section{Conclusion.}

1. When fibrin, platelet-rich plasma is injected into a bone wound, a significant decrease in postoperative edema, painful sensations and local inflammatory complications is noted due to the wide spectrum of its pharmacological action and the ability to diffuse into bone tissue.

2.Clinically, when using a combination of fibrin, platelet-rich autoplasma, there is a significant acceleration of soft tissue regeneration and reparative osteogenesis.

\section{List of references:}

1.Artyushkevich A.C. The results of using platelet-rich blood plasma to eliminate defects of the alveolar process in the experiment / A.C. Artyushkevich, I.A. Shved, D.A. Grichanyuk // Modern dentistry. 2007. - No. 1. - S. 79-84.

2.Kulakov A.A., Amkhadova M.A. Use of platelet-rich plasma to increase bone volume during sinus lifting. // Russian dental journal: Scientific and practical journal. 2004. - No. 5. - P. 10.

3.Yurchenko M.Yu., Shumsky A.B. // Review of equipment and techniques for obtaining autogenous platelet-rich blood plasma in dentistry. New in dentistry. 2003. - No. 7. - S. 46-47.

4.Birnesser H., Oberbaum M., Klein P., Weiser M. The homeopathic preparation Traumeel S compared with NSAIDs for symptomatic treatment of epicondylitis. J Musculoskeletal Research 2004; 8 (2-3): 119-128.

5.Thompson D.M., Rohrer M.D., Prasad H.S. Comparison of bone grafting materials in human extraction sockets: clinical, histologic, and histomorphometric evaluations. Implant Dent. 2006 Mar; 15 (1): 89-96. 


\title{
SEROLOGICAL PICTURE IN CASE OF FALSE POSITIVE BLOOD REACTIONS (FPBR)
}

\author{
Komiljon Abdukarimovich Yuldashev \\ professor, doctor of medical sciences Republican \\ specialized scientific and practical medical center of \\ dermatovenerology and cosmetology of the \\ Ministry of Health of the Republic of Uzbekistan \\ Jumanazar Toshboevich Nuraev \\ doctor, dermatovenerology Tashkent city skin and venereal clinic
}

\begin{abstract}
The purpose of the study is to identify patients with biological false positive reactions to syphilis.
\end{abstract}

Key words: false positive biological reactions, syphilis, treponema, Wasserman's reaction;

In the practice of venereology the false positive serological reactions are important.

Research methods: conducting a standard complex of serological reactions to persons with previously established false-positive serological reactions to syphilis.

Purpose: The study of serological reactions in persons with biological false positive reactions to blood. The purpose of this work was to study the causes of false positive biological serological blood reactions in the examined patients about positive serological blood reactions during medical examinations when applying for a job professional medical examinations and so on.

Material and methods of research: We have made an attempt to interpret false positive biological serological reactions of blood. For this purpose, various causes in the development of the abovementioned conditions have been studied.

False positive biological blood reactions were studied in 46 subjects including 36 women and 10 men. Their age ranged from 4 to 81 years.

For this purpose in persons with false positive biological blood reactions in addition to serological tests the following studies were conducted general blood analysis ultrasound of internal organs, electrocardiography, rheoncephalography, consultation of an optometrist, neurologist, therapist and so on.

Serological reactions were applied Wasserman reaction with Treponemal and cardiolipin antigens microreaction from special reactions immobilization of pale treponemas, RIF - 200, RIF - abs.

Results: The Wasserman treponema bal reaction was positive in 20 and with cardiolipin in 21 of individuals with false positive biological reactions.

Microreactions was positive from + to ++++ in 37 people. The reaction of pale treponema immobilization was positive up to $28 \%$ in 22 patients. RIF -200 from + to ++++ was positive in 11 , RIF - abs in 14 surveyed.

Using ultrasound, the following diseases were identified which we attributed to the causes of false positive biological blood reactions of which chronic cholecystitis was $10 \%$, cholelithiasis $3 \%$, chronic pyelonephritis $3 \%$, chronic prostatitis $3 \%$.

Of the endocrine diseases, diabetes mellitus was detected in $3 \%$ of the examined thyroid diseases also amounted to $3 \%$.

Of infectious diseases as the cause of false positive biological blood reactions tuberculosis accounted for $3 \%$, brucellosis $3 \%$.

Conclusion: Thus in the examined individuals with false positive biological reactions it is important because it is necessary to make the right diagnostic decisions to exclude syphilis.

Thus it can be noted that false positive biological blood reactions are common in the practice of venereology and are accompanied by various serological reactions.

Various somatic infectious and other diseases can be attributed to the causes of false positive biological reactions of blood and their identification is important in the interpretation of false positive biological reactions of blood.

References:

1.Shaposhnikova O.K. Venereal diseases. M. 1980, -528 p.

2.Borisonko K.K. Non-specific positive results serological reactions to syphilis.

3.Methodological recommendations. M, - 1990.-20 p.

4.Proxorenkova V.I. Instructions for the treatment diagnosis and prevention of syphilis.-1996.-29 p.

5.Proxorenkova V.I. Syphilis, M.-2002.-298p. 


\section{TACTICS OF CARING FOR PATIENTS WITH ACUTE DISORDERS OF CEREBRAL CIRCULATION IN FERGANA}

\section{Madjidova Y.N., Usmanova D.D., Mamatalieva J.A.}

City Hospital № 1, Airport st. 2. Fergana city, Fergana branch of the republican scientific center of emergency care. Yuksalish st.4. Fergana city. The purpose of the study is to analyze the state of ambulance patients with cerebrovascular diseases in Fergana.

In Fergana, emergency neurological care is provided on schedule by seven neurological departments of municipal health care institutions. All departments are part of multidisciplinary hospitals. Only two hospitals of these are equipped with a CT scanner (they work only during the daytime). There are about 65 neurological beds in the city. Provision is 4.7 per 10 thousand of population. In each department, beds are allocated to provide care in case of emergency conditions (mainly 6-8 beds). The scheme of care is based on the principle of an early stage-by-stage start of treatment: admission ward - intensive care unit - intensive care wards - neurological beds.

In 2019, 13702 patients (with neurological pathology) were hospitalized. The 1311 patients of these with cerebrovascular pathology (of which 134 - with strokes). In the structure of strokes, ischemic stroke was predominant (up to $80 \%$ ). The ratio of cerebral infarctions and hemorrhages was 3: 1. Patients with transient ischemic attacks were not taken into account. There is no age limit for hospitalization of patients with cerebrovascular pathology. The only contraindication is the agonizing state. From public places, patients are delivered to hospitals on duty, as a rule, within the first 45 minutes. Only the $15-25 \%$ of all patients are hospitalized during the first 6 hours. The 55.7\% of patients are hospitalized in the first 3 days.

Thus, at present, we can conditionally single out three priority economically low-cost tasks to reduce the consequences of strokes: with the aim of early seeking help - spreading knowledge about the first symptoms of stroke among city residents; for early diagnosis - conducting seminars for doctors and paramedics of emergency medical care; for early differentiated therapy - organization of round-the-clock operation of a computed tomography days on duty. 


\title{
CORRECTION OF PIGEON CHEST IN CHILDREN
}

\author{
Mirzakarimov Bakhromjon Halimjonovich \\ Candidate of Medical Sciences, Associate Professor \\ Andijan State Medical Institute, Uzbekistan. \\ Akilov Khabibullo Ataullaevich \\ Doctor of Medical Sciences, Professor \\ Center For Development Of Professional Qualifications Of \\ Medical Workers, Uzbekistan
}

Keeled chest deformity is a congenital defect of development that is characterized by protrusion of the sternum forward . is the second most frequent after funnel deformation and. According to the authors, this pathology is regarded not only as a cosmetic defect, but also as a cause of functional disorders in the respiratory system, heart and even psychology of children. Pronounced $\mathrm{n}$ th cosmetic defect in children older than th age leads to isolation sometimes aggression, violation of social adaptation in society. The main method of treatment is surgical, thoracoplasty.

Purpose: To substantiate the method of IR correction depending on the type of keeled deformity and to determine the optimal age of the operation.

Material and Methods: Over the past 10 years, 86 children of various types of CDC were hospitalized at the Pediatric Surgery Clinic for examination and treatment. Children age from 4 to 14 years old. Distributed on the floor children and boys - 61 Girls - 25 for the type (classification Bairov G.A, and AA Fokin) strain: 1.Manubriocostal type 20 children, this type is characterized by bending forward grip chest .2 ... Corporocostal type: 45 children showed protrusion of the middle and lower third of the sternum. 3. Costal - 21 children, there was a bend in front of the costal cartilage parasternal in the form of a horseshoe deformity.

Anamnestic data indicated that in almost all babies, chest deformities were noticed shortly after birth. With age, the children pointed and smiling painfully sensation of chest and impaired mental status. A psychological examination revealed that young children did not cause any particular concern with an inferiority complex. With age grew impact deformation developed a smiling apathy, shyness dissatisfaction appearance. All of the children after a preliminary examination had been operated, the indication was a cosmetic defect and functional disorders of the chest, which confirms the presence of fatigue, shortness of breath and heartbeat if insignificantly the exertion. As a basis for the thoracoplasty method, we used the Bairov method, which consisted of resection of deformed ribs, transverse sternotomy and fixation with a pressure bandage. We were supplemented to the procedure of: a) myoplastic over corr and spond sternum , b) longitudinal wedge sternotomy at korporocostal type , c) Maximum Feed shortening lower ribs:

Pigeon chest in children progresses with age, leads to functional disorders of the organs of the chest cavity and a violation of the mental status. What is the indication for surgical correction Surgical treatment of this pathology with a modified correction method makes it possible to improve the results in the long term. 


\section{PSORIATIK ARTRITDA ALKOGOLSIZ YOGLI JIGAR KASALLIGINING RIVOJLANISHI VA UNING ISTIQBOLLI DAVO CHORALARI.}

Muhsimova N.R., Razzoqov D.A. Toshkent tibbiyot akademiyasi

O’zbekiston, Toshkent

Izlanish maqsadi: Alkogolsiz yog'li jigar kasalligining psoriatik artritdagi rolini o'rganish va davolashni optimallashtirish.

Psoriatik artrit - autoimmun xarakterga ega bo'lib, asosan teri, keyinchalik bo'gimlar va ichki a'zolar zararlanishi bilan kechadigan surunkali yallig'lanish kasalligi. Psoriatik artritda metabolik sindrom rivojlanish xavfi yuqori turadi. Metabolik sindromda gepatobiliar sistemada eng ko'p kuzatiladigan kasalliklardan biri alkogolsiz yog'li jigar kasalligi hisoblanadi.

Tekshiruv usullari. 62ta bemor organildi. 9ta erkak va 53ta ayol,bemorlar yoshi 18 yoshdan 75 yoshgacha(ortacha yosh 52,5+0,9) tashkil qiladi. Kasallik davomiyligi 6 oydan 26 yilgacha. Erta psoriaz bilan og'rigan bemorlar artritsiz (PsC) psoriaz bilan og'rigan bemorlar bilan taqqoslandi. Klinikaga birinchi tashrif buyurgan bemorda tana vaznining indeksini (TVI) birlamchi tahlil qilingan. Kasallik aktivligini pasaytirish maqsadida barcha bemorlarga diyeta, davolovchi jismoniy tarbiya bilan birgalikda psoriatik artritning bazis davosi va pioglitazon 30mg, gepatoprotektorlar (geptral 400mg) buyurildi.O'tkazilgan davo samarasini nazorat qilish va kasallikning faollik korsatkichini davolash maqsadida har oyda bemorlar qayta ko'rigi tashkil qilindi.

Tekshirishlar natijasi shuni ko'rsatadiki psoriatik artrit bilan kasallangan bemorlarda yog'li gepatoz uchrash xavfi yuqori turadi.

O'tkazilgan bazis davolash fonida bemorlarning ahvoli yahshilandi,bo'g'imlarda og'riq kamaydi, bog'imlar harakati yahshilandi, jigardagi bioximik ko'rsatkichlar AlT va AsT normaga keldi, lipid spektri kamaydi. 1-guruh: Psoriatik artrit jigar jarohatlanishisiz bemorlarda ko'rsatkichlar 90\% bemorlarda "a'lo", 10\% bemorlarda "yaxshi" natija berdi. 2-guruh: Psoriatik artrit jigar jarohatlanishi bilan bemorlarda ko'rsatkichlar 67\% "a'lo", 24\% "yaxshi” va 9\% "qoniqarli" natija berdi.

Xulosa. Kuzatuv va tahlillarga asoslanib psoriatik artrit alkogolsiz yog'li jigar kasalligi bilan kechganda pioglitazon va gepatoprotektorlar effektivligi yuqori baholandi va jigar fibrozi darajasida asoratlanishi oldi olindi. 


\title{
LEVEL OF POPULATION IMMUNITY TO SARS-COV-2 IN THE REPUBLIC OF UZBEKISTAN
}

\author{
Sadirova Shakhlo Sobirovna, \\ Ibadullaeva Nargiz Sapievna, \\ Khikmatullaeva Aziza Saydullaevna \\ Research Institute of Virology, Uzbekistan, Tashkent
}

Background. In February 2020, WHO identified the global COVID-19 epidemic as a pandemic. Uzbekistan, like the many countries of the world, has been involved in a pandemic since March 2020. The registration of COVID-19 cases in Uzbekistan is carried out on the basis of data of positive results for SARS-CoV-2 RNA by the polymerase chain reaction (PCR) method. However, for a number of reasons, in Uzbekistan it was practically impossible to test all sick people by the PCR, same situation happened not only in our country, but in all countries. Therefore, a certain part of people is sick with COVID-19 were not identified. Considered that such unincluded patients are active participants of the epidemic process, also plays active role the formation of population (collective) immunity to SARSCoV-2.

Aim of the study. The study of population immunity to SARS-CoV-2.

Materials and methods. To study population immunity, we used the WanTai SARS-CoV-2 Ab Rapid test (China), designed to detect total antibodies (IgM and IgG) to SARS-CoV-2 in blood. Quality control of this rapid test which was carried out at the Research Institute of Virology of the Ministry of Health of the Republic of Uzbekistan determined $84.0 \%$ sensitivity of the test. In the period from 27th August 2020 to 11th September 2020 blood samples of 86879 people were tested in 14 regions of the republic for the presence of total antibodies to SARS-CoV-2.

Results. The comparative analysis of the number of patients with COVID-19 and those with the presence of antibodies was carried out in 11th September 2020, 6 months after the start of the epidemic in Uzbekistan. The analysis reliably showed that the spread of COVID-19 was much more intense than the official data. According to official WHO data for 6 months (from the beginning of the epidemic until the study date) $0.14 \%$ of the population had been diagnosed with COVID-19. During this period the proportion of the population with antibodies to the SARS-CoV-2 had reached $23.1 \%$. This proves that the actual number of COVID-19 patients on the national average, was at least 165.0 times higher than what was detected by PCR testing. Revealed that only in the Tashkent city difference between the number of registered patients and actual morbidity was minimum (19.0 times).

This is due to the fact that the registration of patients was carried out only on the basis of laboratory confirmation of the positive of SARS-CoV-2 RNA cases, which could not ensure the identification of all patients. In Uzbekistan, as of 11th September 2020, the estimated number of COVID-19 patients was average 7910150 people, and taking into account of an error of the test system used (sensitivity $84.0 \%$ ) 9175800 people. Of these, only $0.5 \%$ were recorded as COVID-19 patients. The level of population immunity to the SARS-CoV-2 virus, formed by the time of the screening, contributed to a decrease in the intensity of the epidemic process COVID-19. If the level of population immunity to the SARS-CoV-2 virus exceeds the threshold of $50 \%$, the stabilization of the epidemic situation will begin.

Conclusions.

1.6 months after the start of the epidemic in Uzbekistan, the level of population immunity to the SARS-CoV-2 virus reached $23.1 \%$.

2.The level of population immunity to the SARS-CoV-2 virus formed by the time of the screening, contributed to a decrease in the intensity of the epidemic process of COVID-19. 


\section{COMPARATIVE MICROBIOLOGICAL EVALUATION OF THE EFFECTIVENESS OF CHEMO-PHOTODYNAMIC THERAPY OF LONG-TERM NON-HEALING PURULENT WOUNDS OF SOFT TISSUES}

Yusupov J.K., Abdullajanov B.R., Babadjhanov A.X.

Andijan state medical institute

Purpose of the study. To evaluate the effectiveness of a new method of treating long-term non-healing purulent wounds (LNPW) of soft tissues by comparative study of the dynamics of changes in the state of the microbial flora of wounds

Material and research methods. The study was based on 132 patients with soft tissue LNPW treated in the clinic of the Andijan state medical institute in 2016-2020. In all patients, purulent wounds were formed at least 14 days before admission, and the average duration of the presence of a wound was 22.6 \pm 1.9 days. All patients were divided into three groups, according to the method of treatment of LNPW. Two comparison groups were formed. The $1^{\text {st }}$ comparison group - 54 patients in whom the analysis of the results for the comparative study was carried out retrospectively. Treatment of LNPW in this group was carried out according to the traditional method. The main group included 38 patients in whom the treatment of LNPW was carried out according to the proposed method. The domestic drug "FarGALS" was used as an antiseptic and wound-healing agent, as well as a photosensitizer for PDT. We used the Matrix laser apparatus as a radiation source for PDT. It uses a semiconductor emitter with a radiation power of $3 \mathrm{~mW}$, spectrum $-337 \mathrm{~nm}$. Radiation is pulsed with a frequency of $100 \mathrm{~Hz}$. The $2^{\text {nd }}$ comparison group included 40 patients. For an objective picture in assessing the results, in this group, patients were treated only with the use of the drug "FarGALS". The age of the patients included in the study ranged from 25 to 75 years. Most of the patients corresponded to the age group from 45 to 60 years.

Studying of microbial contamination of long-term non-healing purulent wounds in patients were carried out immediately when they applied to our clinic, before performing the primary surgical treatment of the wound. Further, the sampling of material from each patient was carried out twice - on 3-5 and 6-8 days after the start of treatment.

Results. In all study groups, staphylococci predominated in the microflora of the wound surface, in most cases Staphylococcus aureus: $42.6 \%$ (23 out of 54 patients) in the $1^{\text {st }}$ comparison group $1,45.0 \%$ (18 out of 40$)$ in the $2^{\text {nd }}$ group and $39,5 \%$ (15 out of 38$)$ - in the main group of patients. There were also cases of combination (association) of Staphylococcus aureus with Pseudomonas aeruginosa, Esherichia coli, Klebsiella spp. and Enterococcus faecalis, which were noted in 14.8\% ( 8 out of 54 ), $17.5 \%$ ( 7 out of 40 ) and $18.4 \%$ ( 7 out of 38 ) in the $1^{\text {st }}$ and $2^{\text {nd }}$ comparison groups, and the main group, respectively. Monoculture in the studied microbiological samples was observed with almost equal frequency $-85.2 \%$ (46 out of 54 ), $82.5 \%$ (33 out of 40 ) and $81.6 \%$ (31 out of 38 ) in the $1^{\text {st }}$ ans $2^{\text {nd }}$ comparison groups, and the main group, respectively.

When analyzing the dynamics of indicators of the microbiological environment during treatment, it was revealed that the frequency of occurrence of Staphylococcus spp. decreased in the $1^{\text {st }}$ comparison group from $61.1 \%$ to $44.4 \%$ on days $3-5$, and to $20.4 \%$ on days $6-8$; in the $2^{\text {nd }}$ comparison group, these indicators were $27.5 \%$ and $7.5 \%$. The main group showed better results - Staphylococcus spp. was sown in $18.4 \%$ of cases on days $3-5$ and in $2.6 \%$ on days $6-8$. In relation to other pathogens, positive dynamics was also noted in all study groups. At the same time, in the main group, on days 6-8 after the start of treatment, only 3 patients showed pathogenic flora: in $1(2.6 \%)$ cases - Staphylococcus spp., In $1(2.6 \%)$ cases - Pseudomonas aeruginosa and in another $1(2.6 \%)$ cases - the association of Staphylococcus spp. with a different flora.

It should be noted that the results of sowing exudate from the wounds of patients showed no growth of any microbial flora on days 3-5 after the start of treatment in $73.7 \%$ (28 out of 38 patients) of cases from the main group, in $50 \%$ (20 out of 40$)$ - in the $2^{\text {nd }}$ group $(\chi 2=4.618 ; \mathrm{df}=1 ; \mathrm{p}=0.032)$ and in $27.8 \%$ (15 out of 54$)-$ in the $1^{\text {st }}$ group $(\chi 2=18.882 ; \mathrm{df}=1 ; \mathrm{p}<0.001)$. By $6-8$ days after the start of treatment in the main group of patients, the analyzed parameters increased to $92.1 \%$ (in 35 of 38 patients) versus $85.0 \%$ (in 34 patients; $\chi 2=0.964 ; \mathrm{df}=1 ; \mathrm{p}=0.327$ ) and $64.8 \%$ (in 35 patients; $\left.\chi^{2}=9.130 ; \mathrm{df}=1 ; \mathrm{p}=0.003\right)$ in the $1^{\text {st }}$ and $2^{\text {nd }}$ comparison groups, respectively. 


\section{Conclusions.}

Thus, the pathogenetical effect of the combined method of photodynamic therapy for long-term non-healing soft tissue wounds is characterized by an increase in the bactericidal properties of antiseptic action, the balance of the drug.), whereas local monotherapy in these terms provided strict fit in $50 \%$ (in 20 of 40 patients in the $2^{\text {nd }}$ comparison group; $\chi 2=4,618 ; \mathrm{df}=1 ; \mathrm{p}=0,032$ ), and traditional approaches only in $27,8 \%$ in 15 of 54 patients in tne $1^{\text {st }}$ comparison group; $\chi 2=18,882 ; \mathrm{d}=1 ; \mathrm{p}<0,001$ ), for 6-8 days these indicators increased in the main group to $92,1 \%$ (in 35 patients) against $85,0 \%$ (in 34 patients; $\chi 2=0.964 ; \mathrm{df}=1 ; \mathrm{p}=0.327$ ) and $64.8 \%$ (in 35 patients; $\chi 2=9,130 ; \mathrm{df}=1 ; \mathrm{p}=0.003$ ). 


\title{
DEVELOPMENT OF SPEECH IN CHILDREN WITH HEARING DISABILITIES
}

\author{
Student of Tashkent State Kamoliddin Behzod Institute \\ Ziyotova Malika Mashrabovna
}

\begin{abstract}
Annotation: begins with the perception and perception of the surrounding environment, that is, the reflection of real objects and events in the child's mind. The child's perception is much improved in the first years of life, and at the age of two he begins to differ from each other depending on the color, shape, size of objects, distinguishes a familiar tone, and so on. It develops a variety of sensory abilities: sight and sight, hearing and hearing, the ability to distinguish objects according to external signs, the ability to imitate what is less visible and heard.
\end{abstract}

Keywords: deaf from birth, children with hearing loss..

The child should be able to make different impressions, see and touch objects, observe the work of adults, hear different sounds. . Speech has a great impact on the development of mental processes, cognition, memory, etc., children's activities. As a child begins to develop speech, the role of adult speech as an educational tool increases. The formation of a child's personality begins in the first days of life. Based on what he sees and hears every day, the child shows little attitude to the being and the people around him, the behavior of adults, the child's assessment of the events that take place in his work - all this affects the formation of the child's spiritual image. Violation of certain conditions necessary for the development of the child in the womb and after birth can lead to various anomalies, ie physical or mental defects. In the field of defectology, work is carried out on different categories of children with anomalies: children with hearing impairments (deaf from birth, children with severe hearing loss, children with subsequent hearing loss); poor eyesight (blind children); blind-deafdumb children; oligophrenia (debil, imbesil, idiot children); children with severe speech defects; children with defects in the movement base organs; children with mental retardation. Abnormal children should be brought up and educated in special educational institutions. Only defects that have a strong impact on a child's overall development can be considered abnormal. For example, if a child has only the left ear and this defect does not affect the overall development of the child, he or she will not be considered an abnormal child.

This defect cannot be considered an anomaly in adults even if the defects that appear for obvious reasons do not affect their overall development. Severe abrupt changes in the physical and mental development of abnormal children have a negative impact on the composition of the boal personality. Therefore, special conditions must be created for the upbringing and education of such children, that is, they must be taught and educated in special kindergartens and schools on the basis of special programs and textbooks.

Any abnormal development may be related to organic or functional changes in the central and peripheral nervous system. Various deficiencies in child development can occur as a result of an uncomfortable environment, improper parenting education.

For example, poor family conditions, pedagogical neglect, the teacher's mistreatment of the child, and many other factors have a negative impact on the child's development, causing him to not be able to absorb the program materials well, and to become involved in underage students. However, we do not include such a child in the category of anomalous children, because the defects in his development are not due to any organic or functional pathological changes in the body, but are due to other reasons. Educators and teachers need to be able to distinguish such children from anomalous children. After graduating from special schools, visually impaired children work in the institutions of the Republican Society of the Blind. Engaged in intellectual activities (writer, poet, high school and high school teachers, musician, etc.). Thus, there are great opportunities to develop visually impaired children through education. Properly covered, it will withstand a great deal of adverse conditions.

\section{References:}

1.Law of the Republic of Uzbekistan «On Education». -T., 1997.

2.National Training Program of the Republic of Uzbekistan. -T., 1997.

3.«Fundamentals of Defectology» - T., 1989.

4.P.M.Po'latova. Special pedagogy. T., 1999

5.PM Polatova «Implementation of educational work in auxiliary boarding schools.» Tashkent. 1996. 


\section{DIFFERENTIATED THERAPY OF CHRONIC HEPATITIS B AND C IN PREGNANT WOMEN.}

\section{Zufarova Sh.A., Mirzaabdullahozhieva O.U., Yuldasheva O.S. Andijan State Medical Institute, Andijan.}

Introduction: As recommended by the European Association for the Study of the Liver (1999) and WHO recommendations. pregnancy is not contraindicated in women infected with hepatitis viruses. All pregnant women are subject to mandatory examination for the presence of hepatitis B and $\mathrm{C}$ viruses. Chronic viral hepatitis, which occurs in women of childbearing age, causes a number of problems associated with the possible risk of complications both during the course of the disease in connection with the onset of pregnancy, and the risk for the child due to possible complications of pregnancy, perinatal infection with hepatitis viruses, as well as the use of certain medications during pregnancy. Timely detection and treatment of chronic viral hepatitis before pregnancy is extremely important. A careful assessment of the degree of risk to the mother and the fetus in each case is necessary to choose the right tactics for managing pregnancy.

It is recommended to take into account a number of provisions in the medical treatment of pregnant women. 1. The placental barrier does not completely protect the fetus from the effects of toxic substances entering the body. 2. The rapidly growing organs of the fetus are vulnerable to toxic effects due to active cell division. Since the time of the completion of organogenesis cannot be predicted with absolute certainty, it is recommended to prescribe medications only after 4 months of pregnancy. Excretion of drugs from the fetal blood does not match their excretion from the mother's blood. 4. There is no correspondence between the concentration of the drug in the mother's blood and her breast milk.

5. Caution is most needed with high doses and long-term treatment, and the duration of treatment, even in small doses, is more dangerous than taking high doses for a short time. It is recommended to stop using highly active drugs. 6. If necessary, drug therapy should use drugs that have been widely used in pregnant women for many years. 7 . Combined treatment with several drugs has a more harmful effect on the fetus. The following recommendation may be optimal: do not prescribe more than 3 drugs at the same time, well justifying their use.

Dispensary observation and differential treatment of chronic viral hepatitis $\mathrm{C}$ in pregnant women, taking into account the degree of activity, has not been sufficiently developed.

Purpose of the research: To study the effectiveness of various treatment regimens for pregnant women with chronic hepatitis $\mathrm{B}$ and $\mathrm{C}$, taking into account the degree of activity.

Materials and methods of research: 90 pregnant women with chronic viral hepatitis B were examined. Of these, the minimum degree of activity - 32, the weakly expressed degree of activity 29 , the moderate degree of severity - 20 and the expressed degree of activity - 10 pregnant women. There were 38 pregnant women with chronic viral hepatitis C. The minimum degree of activity - 17, a weakly expressed degree of activity - 15, an average degree of severity - 4 and a pronounced degree of activity - 2 pregnant

The diagnosis was verified based on data from the epidemiological history, the results of clinical, biochemical and immunological analysis. Ultrasound examination in B-mode was carried out on a MINDRAY DC-6 Expert apparatus using a 2.5-10 MHz convex transducer.

Research results: For the treatment of chronic viral hepatitis of minimal activity, the following drugs were prescribed: Essentiale $\mathrm{N}+$ proteflazid + duspatalin + multivitamins according to the instructions. Pregnant women with duodenostasis syndrome are additionally prescribed supplements and Almatsid gel.

Pregnant women with chronic viral hepatitis B and C of a mild degree of activity were used: Essentiale $\mathrm{N}+$ proteflazid + ursosan + duspatalin + multivitamins according to the instructions. Pregnant women with dyskinesia of the biliary tract and intestines were additionally prescribed ursosan + cinarix according to the instructions.

Pregnant women with moderate chronic viral hepatitis $\mathrm{B}$ and $\mathrm{C}$ were treated with: Essentiale $\mathrm{N}+$ proteflazid + ursosan + cynarix + multivitamins. Pregnant women with gestational pyelonephritis were additionally used the drug Conephron, with cholestasis syndrome Heptral + glutione + proteflazid + 
ursosan + multivitamins were prescribed according to the instructions.

Pregnant women with a high degree of activity were treated with Heptral + Essentiale + Proteflazid + Ursosan + Cynarix + Multivitamins according to the instructions. With the development of II - III degree hepatic encephalopathy syndrome, the complex included Glutione + rheosorbilact + hepamerts + prednisolone.

The schemes were tested in inpatient (8-10 days) and outpatient (4 weeks) treatment. Each scheme was prescribed in therapeutic doses, subject to the regimen and dietary table. Therapeutic efficacy was assessed by the disappearance of clinical syndromes, normalization of laboratory biochemical blood parameters and a decrease in the concentration of viremia.

Conclusions: The recommended methods of treatment, taking into account the degree of activity of the systemic manifestation of chronic hepatitis B and C in pregnant women, ensured stabilization of the pathological process of the liver and the physiological course of pregnancy. No side effects of the proposed combination of drugs have been identified. 


\title{
PEDAGOGICAL SCIENCES
}

\section{METHODS OF TEACHING ENGLISH LANGUAGE VOCABULARY TO THE UZBEK STUDENTS}

\author{
Specialized Branch of \\ Tashkent State University of Law \\ Department of "General Education Disciplines" \\ English Teacher \\ Allanazarova Mamura \\ m.akhmedovna@mail.ru
}

\begin{abstract}
Assimilation is the ability to use or recognize vocabulary fluently in speech. Possession or mastery means knowing the level of skill. Simple cognition refers to the ability to memorize the meaning of a word or to recognize its form. The consequence of knowing is mastery, that is, the use of a unit of language in speech. Vocabulary control is done through direct speech activities, not through special inquiries. When speaking on a topic, reading / listening comprehension creates sufficient conditions to test the student's lexical skills. Despite the fact that the goal of studying a foreign language lexicon was to conduct speech, working on lexical units during the period of acquaintance (Presentation, Presentation) and exercise (training, activation) was the primary task, when going to the stage of application, speech serves as the primary, and lexical as the engine, that is, "building material". Consequently, it is natural for lexical skills to be included in the composition of speech skills.
\end{abstract}

Key words: foreign language, learners, well-structured, knowledge, skills, abilities, speech, positively assess, informants, alphabetical order

In order to create a system of exercises on the teaching lexicon of the English language, first of all, a test on the topic of knowledge was conducted from the students of the Uzbek auditory. The total number of test takers was 24 and the total number of questions was 30 . The Test consisted of multiple-choice type questions and included a variety of questions related to students ' familiarity with vocabulary, interpersonal situations in the English lexical of the native language, and the ability to correctly select the form and meaning of words.

According to the results of the tests conducted in 2 first-stage groups, the errors made by the students were calculated and the level of knowledge on the total Fe was determined

To prevent possible interpersonal situations that may arise due to the results of Test assignments and different aspects of the lexical system in the two languages; it was aimed to compile exercises on the teaching lexicon that serves to develop communicative competence of students. As an example of the systematic submission of exercises, 15 exercises and various interactive exercises were developed.

Exercise is a kind of activity that is performed regularly, aimed at mastering some kind of speech activity. In the methodological literature, the variety of exercises, their typology was approached differently by different criteria, hence their classification is also different. But the main three exercise groups occupy the most oily place (Djusupov, 1991: 196-198): a) exercises aimed at studying the structure of the language; b) exercises aimed at studying the dynamics of the language; d) exercises aimed at developing speech activity.

The principle of intensification (acceleration) of students ' educational activities is closely related to the principles of activity, motivated education. Intensification of students ' educational activities is carried out in the following ways::

- effective use of training time; 
- the use of effective methods and methods in the training process;

- to take into account the age characteristics, memory, attention, thinking and mastering abilities of students in the use of methods and techniques, etc.

Exercises aimed at preventing this condition have been formulated on topics where interpersonal problems may arise;

Based on the systematic approach in the set of exercises, a sequence of tasks was created, that is, from light to complex, from PrEP (pre-communicative) exercises to mass (communicative) exercises. As much as possible, the contexts inherent in the English and Uzbek culture were chosen and introduced into the exercises. In accordance with the state standard of education and the knowledge base of the students, exercises of difficulty corresponding to the B2 level were given.

In our country, the government is carrying out extensive work to further improve the sphere of teaching foreign languages, to increase the literacy of the population in terms of language, to bring the Uzbek name to the world, to learn a foreign language. Today, scientific work is being created to produce and implement more effective methods of teaching a foreign language, especially English, and the scientific and practical base of foreign language teaching methodology is being replenished. In the same science itself, the attitude to language has changed, instead of the idea of learning, the idea of mastering appeared. This in turn led to the emergence of new methods and approaches in the methodology of teaching foreign languages.

To ensure the success of the lesson and to ensure that learners can access full foreign language communication in the lesson, the importance of the English language learning lexicon is paramount. Lexicon is of great importance as an object of methodology, and its teaching is carried out mainly in three stages:

1. The presentation of the lexicon is a teacher's explanation for acquaintance with the word, the form, meaning and application of the word.

2. Lexical exercises-the period of application of the familiar lexical in the process of speech, that is, the initial reinforcement of the material.

3. Application of lexicon-the word studied is mastered in the order of skills and qualifications in the types of speech activity.

In teaching foreign languages process the formation of communicative competence in students is the main goal of today's methodology. And communicative competence, in turn, includes several small compensations, and the first of them is linguistic competence. When it comes to linguistic competence, it is understood that the student has excellent knowledge and skills in English Vocabulary. Mastering the vocabulary of the language is taught in educational institutions on the basis of a traditional system of exercises. These include exercises to listen to lexical units, exercises to see lexical units, exercises to say and write lexical units, prescription (passive) and reproductive (active) lexical exercises, etc.

Relatively difficult and the most difficult lexical units make up the content of teaching vocabulary. When we say the meaning of teaching lexicon, because of its difficulty, words that require special exercises and are taught by interpretation, form a certain shortening of the lexical minimum are understood. Difficulty is observed in the form, meaning or application of the word. Consequently, the word can be functional, semantic, formally difficult, or one of them is either two, or even three sides difficult.

As it turned out from the exposition, the level of mastering of the English Language Teaching lexicon of students in the Uzbek audience is not satisfactory $(63,4 \%)$. In overcoming this issue, it would be worthwhile to give more confidence to the organization of training hours devoted to the English Language Teaching lexicon. In the above-mentioned teaching aids, little importance is attached to the teaching lexicon of the English language. To eliminate this problem, the body needs to create a special system of lexical exercises.

From the practical analysis of the constructive part came the following conclusions:

- The need for systematic sorting of lexical material;

- The need to attach lexical and lingvoculturology material to the English language teaching process;

- To develop a system of scientifically based exercises for Uzbek students to improve their knowledge of the concepts of the lexical layer on the teaching lexicon of the English language and to prevent interpersonal situations in speech.

- In accordance with the state standard of education and the knowledge bays of the students, exercises of difficulty corresponding to the B2 level were given. 
- As much as possible, the contexts inherent in the English and Uzbek culture were chosen and introduced into the exercises.

The principle of complex organization of the educational process provides for the organization of speech activities in various forms by linking phonetic, lexical, grammatical material. The complex organization of the educational process requires the joint implementation of educational goals (practical, educational, educational, developmental).

Such exercises are practical exercises aimed at further enriching the vocabulary in the English Language Teaching and learning system of first-year students, forming lexical skills, transferring it from temporary memory to permanent memory. Despite the fact that some of the lessons are relatively complex, they are able to give students the ability to work with dictionaries, to understand them through context.

In summary, an exercise system should be structured to study every English language learning lexical work. Exercises can be created differently and with different difficulty, based on different styles. However, according to the recommendations in this scientific work, it is worthwhile to create exercises based on a communicative approach, covering the contexts inherent in different mother tongue and foreign language. The main thing is that when solving exercises, students should not suffer from interpersonal situations by comparing lexical units of English and Uzbek languages. This is evidenced by the fact that the system of exercises and textbooks should be rich in assignments, which also include the analysis of the mother tongue and foreign language in the study.

References:

1.Mirolyubov A.A. Metodika ili lingvodidaktika inostrannix yazikov . Inostrannie yaziki v shkole. 2005.№ 2.

2.Oliy Majlisining XIV sessiyasida so'zlangan nutk. -T.: Uzbekiston, 1999. - 370 b.

3.Passov Ye.I. Osnovi kommunikativnoy metodiki obucheniya inoyazichnomu obsheniyu. - M., Russkiy yazik 1989, - c. 144-145.

4.Saynazarov X. Obuchenie leksike angliyskogo yazika v starshix klassax uzbekskoy shkoli: Kand. diss. - L., 1982.

5.Serova T.S., Chaynikova G.R. Sistema uprajneniy dlya razvitiya leksicheskoy kompetensii: stat'ya. - M.: Professional'noe obrazovanie, 2013. - c 92-93.

6.Starodubseva O. G. Tipi uprajneniy dlya formirovaniya leksicheskix navikov usinoy rechi $\mathrm{v}$ yazikovom vuze: stat'ya. - Nauchno-pedagogicheskoe obozrenie. Pedagogical Review. 2013. 2

7.Sternin I. A., Sternina M. A. UDK: Vidi i metodi sopostavitel'nix issledovaniy leksiki. - 2016. - s. 66-67.

8.Shanskiy N.M. Leksikologiya sovremennogo russkogo yazika. - M: 1972

9.Shatilov S.F. Salomatov, K. I. Professiogramma uchitelya inostrannogo yazika. - 1977.

10.Sherbak Z. A. Trebovaniya k uchebno-metodicheskomu kompleksu po angliyskomu yaziku kak instrumentu obespecheniya kachestva uroka i kachestva obrazovaniya. - M.: Prosveshenie, 2012. - s. 2-3. 


\title{
SOCIAL ISSUES OF ACTIVE CIVIC POSITION AND INITIATIVE DEVELOPMENT IN YOUTH
}

\author{
Egamberdieva Aziza Mustafaevna \\ Teacher of Navoi State Pedagogical Institute
}

\begin{abstract}
Rezume: The article examines the views on strengthening the active civic position among the youth of our country as an object of study of today's social reforms. It is a philosophical study aimed at increasing the initiative of young people in society, protecting the interests of the people in the ideological, political and legal spheres.
\end{abstract}

Key words: youth, active citizenship, society, initiative, need, national idea, politics, state.

Today, there is every reason to believe that the works and research devoted to the analysis of issues of ideological and ideological needs of society, the role of active citizenship and initiative in young people have become an integral part of scientific research in this area. In particular, M. Yuldashev conducted a doctoral dissertation on the analysis of issues related to the active civic position and initiative of young people in the large-scale research conducted in our country during the years of independence. Implemented by E. Bobomurodov, S. Juraev, G. Tulenova, Z. Kadyrova. These studies show that, first, the formation of the civic position of the younger generation is a pedagogical process that ensures the expediency of the relationship between teachers and educators, the result of which is the conscious attitude of young people to society and the state, people and socio-political events. based on civic beliefs. Second, the pedagogical model of shaping the civic position of young people includes: goals; tasks; features; the content of youth activities at each stage of the formation of civic position; forms; methods; buildings; Criteria and indicators of civic position formation are of paramount importance. The implementation of this pedagogical model will help to involve young people in activities of social significance, to actively participate in various areas of activity in accordance with their interests.

It also provides ample opportunities for young people to develop organizational skills, gain experience in self-governance, and demonstrate a civic stance. Third, the formation of the civic position of young people is characterized by the following indicators: the ability to interpret, analyze and interpret social and political events; ability to perform social activities; manifestation of activity in the social life of the village, city, region, country; initiative in the organization of various works; including the desire to take an active part in self-government activities, political events, and civic movements. In this regard, LE Tursunov said, "The process of radical change in world social development today shows the need to develop the legal consciousness and political culture of the population, especially youth. Indeed, some imperfections in the legislation, the collapse of guarantees of protection of rights and freedoms, the deformation of the legal system are leading to legal and political nihilism in the minds of young people. This raises the issue of shaping the legal and political consciousness and culture of young people in the world as an ideological, psychological process that reflects the social reality. In particular, the ongoing political and legal changes in the world, the pandemic situation in the world has made it a matter of raising the legal and political culture of young people "[1. 5] writes.

Criteria of activity, emotional and voluntary activity play a priority in the formation of civic position of young people. Effective indicators of such activity criteria are: the first is an indicator of activity, according to which the ability of young people to interpret, analyze and interpret social and political events; desire to engage in social activities; manifestation of activities in the public life of the university, city, region, country; the presence of initiative in the organization of various public works; self-government activities, political activities, the desire to actively participate in various civic movements are important. The second is the indicators of emotional criteria, according to which the positive attitude of young people to the fulfillment of their civic duty, strict adherence to the moral and ethical norms established by society; active participation in socially important events and a positive attitude to future professional activity are of paramount importance. The third is the voluntary criterion, according to which the choice of young people in accordance with ethical norms and the manifestation of voluntary actions in assessing the need for civic behavior; the ability to subordinate personal interests to collective interests; adhere to the rules and norms of behavior existing in society; striving for self-discipline; the ability to engage oneself in good deeds; the presence of perseverance 
towards oneself and others takes precedence.

The ideological needs and interests of society greatly help to ensure active citizenship and initiative among young people. Therefore, the issue of ensuring active citizenship and initiative in young people on the basis of national ideas and ideologies is of great importance in today's socio-political system. Enhancing the role of a set of ideological needs and interests of society in ensuring active citizenship and initiative in young people is also one of the priorities of public policy, which is a necessary requirement of universal democratic principles. As A. Mukhtarov rightly noted, "Ideology is inextricably linked with the vital interests and needs of a particular nation and people, expressing their dreams and goals for centuries, nourished by the historical past, traditions, customs and national and universal values of the people. , is a system of ideas that serves as a bridge between the historical past of this nation and the present "[2.13].

While the systematization of the ideological and ideological needs and interests of society is of social importance, increasing the active civic position and initiative of young people is also a social process. Again, the ultimate goal of both concepts is man. Consequently, the ideological needs and interests reflect the essence of society. It requires people to work together for development. The effective organization of the process of increasing the active civic position and initiative of young people in society ensures the practical implementation of ideological and ideological reforms. The ideological and ideological needs of the society, the perception of their interests by the younger generation and the development of their active citizenship and initiative. In this regard, today Sh.K.Agabaev said: "It can be said that the youth has become a decisive force in the formation of a democratic state and a free civil society in our country. Our youth has been defending the name of Uzbeks and Uzbekistan at international science olympiads, sports competitions, music and art festivals. At the same time, the formation and development of a culture of tolerance, which is the most important spiritual value in the minds of our youth, has become one of the main directions of state youth policy in our country "[3.21].

Consequently, the fact that the development of active citizenship and initiative of young people is a complex social phenomenon is clearly reflected in its essence. Active citizenship and initiative are changing phenomena, and they will change as society develops. Changes in the ideological and ideological needs and interests of society are associated with a unique combination of stable and unstable, old and new components. Stable parts stem from traditions that embody the ideological experience of the past. Traditions ensure succession in the development of ideological systems. Any renewal is either compatible with ideological-ideological traditions, or ideological-ideological traditions deny them. From this point of view, ideological needs and interests are a form of radical reform - renewal of society.

The mechanisms of development of ideological and ideological needs and interests include both the disruption of tradition and the emergence of new ones. These processes can take the form of a conflict between outdated ideological beliefs, habits, systems of traditions and a new system of values and norms. That is why finding the optimal ratio of ideological traditions and innovations is the main problem of any reformist activity. Therefore, since ideology is an ideological whole that unites the common interests of the people, a series of programs on "National idea - a vital need", "National idea - my idea" and "National idea - my idea" broadcasts can be organized "[2.33].

The process of increasing the active civic position and initiative of young people is also determined by the fact that it is an important factor in the realization of the national idea. Increasing the active civic position and initiative of the younger generation plays an important role in achieving the goals of the national idea. The reason is that the national idea is to build a new democratic society that will ensure the full realization of the socio-political interests of young people. The establishment of a democratic state governed by the rule of law will accelerate the process of increasing the active citizenship and initiative of young people. The interdependence of ideological and ideological needs and interests in the development process is also determined by the fact that they are essentially mutually exclusive.

The stages of formation of civic position of young people are as follows:

the first is the analytical stage, ie the ability of young people to assess their knowledge necessary for life in civil society, to form their own conclusions, to respond independently and actively to different social situations, to determine the degree of manifestation of their civic qualities.

Second, the stage of education implies the process of acquiring knowledge about the civic position of young people and their knowledge necessary for life in political, historical, economic, legal, environmental and other similar civil society. 
The third is the cultural stage, which understands the process of consciously internalizing civic knowledge in young people on the basis of their personal spiritual, moral and cultural needs, bringing it into line with their vital values.

The fourth stage is based on practical activity, according to which the manifestation of civic behavior of the younger generation in daily practice, civic activity, their participation in increasing the activity of civil society institutions is of paramount importance.

The fifth stage is the stage of pedagogical education and upbringing. In this process, the content of the pedagogical model of formation of civic position of the younger generation is supplemented with content, the organization of their gradual rational social activity, acquisition of fundamental and professional knowledge, introspection, self-education, self-awareness. ; responsibility, initiative, development of discipline, and extracurricular socially useful work, sports and recreation, active participation in specific creative activities.

The sixth stage is a heuristic stage, which develops the ability of young people to innovate in various spheres of state and public life, to improve the skills of working with hard-working, creative people who work effectively in various fields.

The seventh stage is the stage of socio-political activity, in which it is important for young people to understand the essence of the socio-political changes taking place in society, to improve their organizational and leadership qualities.

In summary, the analysis of the concept of civic position allows us to identify different approaches in understanding its important foundations. Thus, the civic position is understood as a product of personal knowledge. Because in this process the integral quality of the individual; civil, legal or ethical complex; various aspects of the relationship - spiritual, labor, moral, etc .; the social or ideologicalethical criteria of personality formation take precedence. Based on the logic of the research, in the structure of the civic position we distinguish cognitive, motivational, moral, behavioral components, and it is expedient to study their important features into the following components. The first is the cognitive component, which includes civic knowledge. This component also demonstrates the ability of young people to understand socio-political processes and events, to analyze the social situation and problems, to express their views freely through active citizenship. The second is the valuemotivational component, which in itself reflects the humanistic direction of an individual's attitude toward society, labor, people, and himself. It will also be possible to form directions of civic values, to ensure the assimilation of its social norms of behavior, to understand their importance for one's own life. The third is the behavioral component, which reflects the ability of young people to fulfill their civic responsibilities responsibly and to adhere strictly to social and legal norms. That is, a person's behavior, his active participation in various levels of social activity is of paramount importance.

List of used literature:

1.Tursunov L.E. Socio-philosophical problems of development of legal and political culture in youth. Abstract of the dissertation for the degree of Doctor of Philosophy (PhD) in Philosophy. Samarkand, 2020.

2.Mukhtarov A. Unity of needs and interests in the development of the national idea. Abstract of the dissertation for the degree of Doctor of Philosophy. - Tashkent, 2011.

3.Agabaev Sh.K. In the process of globalization, the political tolerance of young people as an important factor in the stability of society. Abstract of the dissertation for the degree of Doctor of Philosophy (PhD) in Political Science. - Tashkent, 2020. 


\title{
EFFECTIVE READING STRATEGIES FOR INCREASING THE READING COMPREHENSION LEVEL OF FOURTH-GRADE STUDENTS
}

\author{
Ergasheva Matluba Sabirovna \\ (Teacher of school 223, Tashkent, Uzbekistan)
}

\begin{abstract}
Annotation: This article identified the common reading problems that negatively impact reading comprehension of fourth graders. It also investigated the effective reading strategies that special education teachers have utilized to improve reading comprehension levels of the students in resource room settings.
\end{abstract}

Key words: reading comprehension, Read-aloud strategy,PIRLS assessment

It is undeniable fact that Reading comprehension is a critical learning skill for all students, as it is "the process of simultaneously extracting and constructing meaning through interaction and involvement with written language". Without any doubt we can say that understanding words' meaning, analyze the authors points of view and aim for writing and gaining knowledge of new words are all very important reading skills that support reading comprehension. Students need reading comprehension skills to successfully accomplish the educational goals and expectations, which are required in the classroom settings. For example, having the ability to understand textual information play a critical role in helping learners to quickly locate information that is pertinent to the text, exclude information that is irrelevant to the text, and identify the important information to focus on. Academic success also requires students to be able to understand, analyze, and apply information they gathered through their reading. The importance of being able to understand written materials increases significantly in all academic areas as students move from one grade to another .In contrast, not being able to successfully comprehend can prevent students from learning, retaining information that they read, and graduating from school, which will negatively impact different aspects of their lives later on .Reading difficulties negatively impact different aspects of students, including their educational progress, self-esteem, attitudes about reading and learning, motivation to read, career choices, social-economic status and expectation for future reading success. Not only is reading comprehension a valuable skill for learning in school, but in order to successfully interact in everyday life, individuals need reading skills to read and understand labels, directions, job application forms, and newspapers. Also, individuals need reading skills in order to be able to have and maintain a job and successfully engage in different daily activities and live independently .The need for reading comprehension becomes very critical when thinking about the negative consequences of not being able to read in critical situations. For instance, not being able to read and comprehend dosage directions on a bottle of medicine or caution on a container of dangerous chemicals may put the individuals in a very dangerous situation that threaten their safety and lives. Those who do not possess the ability to understand what they are reading are put at a disadvantage in every educational and personal life situation. Thus, the critical role that reading plays in students learning beyond fourth grade emphasizes the importance of identifying struggling readers in their early grades and providing them with the most appropriate reading strategies. "The article strongly supports both the vital role of early identification in the prevention of reading difficulties and the urgent need to teach children to read during the first few years of school so that they can "read to learn" in grade 4 and beyond". To avoid most of the long-term negative effects, teachers are required to utilize and integrate reading comprehension strategies in their daily instructional practices in order to increase the reading comprehension level of students with learning disabilities. Also, finding of previous research suggested that students who face difficulty with reading in lower grades will continue to struggle with reading in their later grades. Thus, there is a need for conducting more studies to examine the instructional strategies that have been used by experienced special education teachers to improve reading comprehension level for elementary students with learning disabilities .In addition, due to the limited studies that have been conducted in Uzbekistan to examine the most effective reading comprehension strategies for elementary students, conducting this study may contribute to producing some 
strategies and practices that could be used by both special and general education teachers in order to improve the students' comprehension. For example, one study was conducted by myself to examine the effectiveness of using read-aloud strategy on reading comprehension of 223 school's students. The study took place in that school during the winter of 2021 . The participants were 41 uzbek 4 th grade students. Before conducting the intervention, i have observed the students' behavior during the 10 reading lesson and recorded field notes. Also, a pre-test was administrated to all participants to measure their comprehension levels. All the question in the pre-test were taken from the fourth grade reading textbook. Also, in order to measure the students' affinity for reading, the researcher conducted a survey with closeended questions. In this study, the researcher was in charge of implementing the strategy. He provided the students with an explicit explanation about both reading comprehension and read-aloud strategy. He taught read-aloud to the students daily for two weeks during the reading instructional time. Each session took approximately 20-30 minutes. At the end of the study, I have remeasured the students' comprehension through administration of a posttest, which had exactly the same questions as the pre-test. The results indicated that readaloud strategy positively impacted the comprehension of fourth grade Uzbek students. It also helped the students to make a connection between their previous experiences with the texts and share their opinions with others.

Nowadays I am conducting trainings on Progress in International Reading Literacy Study among $4^{\text {th }}$ grade students at school 223 .PIRLS is a carefully constructed reading assessment, consisting of a test of the reading literacy of fourth-grade students and questionnaires to collect information pertaining to fourth-grade students' reading literacy evaluation.

Reference:

1.Adams, M. J., \& Collins, A. (1985). A schema-theoretic view of reading. In Singer, H \& Ruddell, R. B. (Eds.), Theoretical models and processes of reading (pp. 404-425). Newark, DE: International Reading Association.

2.Baretta, L., Tomitch, L., MacNair, N., Lim, V., \& Waldie, K. (2009). Inference making while reading narrative and expository texts: An ERP study. Psychology \& Neuroscience, 2(2), 137-145. 


\section{PHYSICAL TRAINING OF ASSISTANT REFEREES ON FOOTBALL INCREASE}

\section{I.X.Qutlimurodov. UzSUPES, independent researcher}

Аннотация. В данной статье приводится информация о том , как определить быструю выносливость футбольных помощников хакеров, с помощью которой физическая подготовленность хакеров сравнивается с международными требованиями. Ключевые слова: футбол , судья, выносливость, спорт, метр, скорость, поле.

Annotation. This article provides information on how to determine the rapid endurance of football assistant hackers, through which the physical preparedness of hackers is compared to the international requirements. Keywords: football, referee, endurance, sports, meter, speed, field.

Keywords: football, referee, endurance, sports, meter, speed, field.

In recent years, special attention has been paid to football in our country. The Decree of the President of the Republic of Uzbekistan Sh.M.Mirziyoev dated December 4, 2019 No 5887 "On measures to bring the development of football in Uzbekistan to a completely new level" creates a solid foundation for the development of this industry. On the basis of this decree, a large-scale work is being carried out in our country today. In particular, one of the main issues raised in this decree is aimed at improving the physical fitness of players. The high level of physical fitness of the players ensures fast and accurate execution of technical and tactical actions on the field. This will increase the speed of the game and serve as a basis for ensuring the success of the team. This factor also places high demands on the physical fitness of the referees involved in a football game. The speed of modern football raises the problem of regularly monitoring the training of referees in order to properly assess the situations that arise in the game and to prevent a negative impact on its outcome.

Purpose of the work: To increase the special endurance of different categories of football referees.

The study found that 10 assistant referees on football had a special endurance test using the ARIET test.

This test is performed by running a distance of 20 meters and (Figure 1).

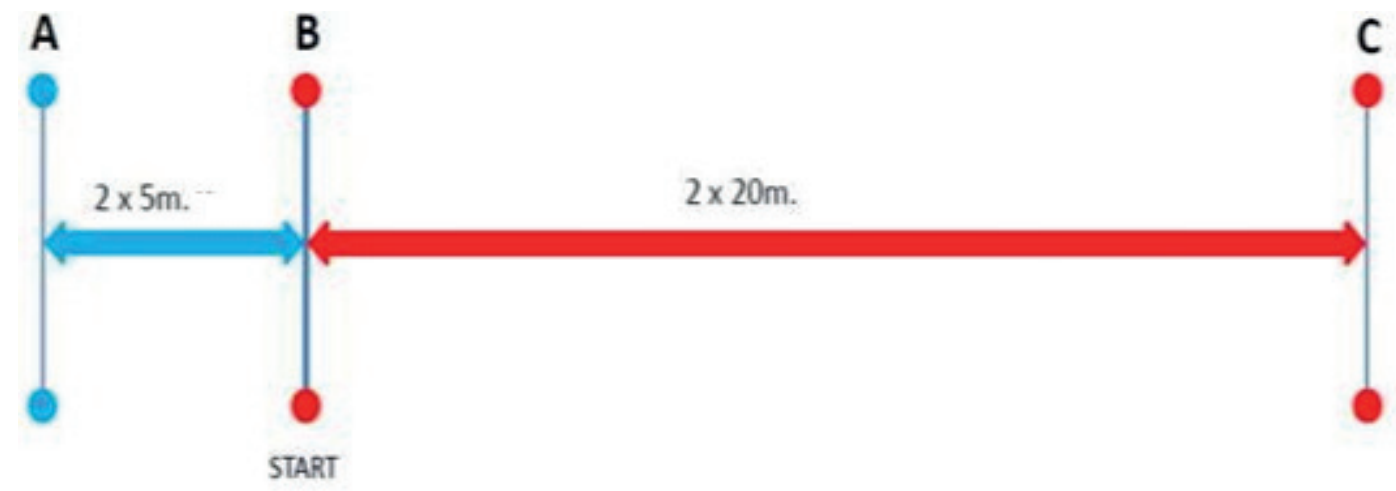

Figure 1. Schematic of the "Yo-Yo" test.

from the Assistant Referees. X.Bokhodirov passed this test at a distance of 600 meters (Table 1). The results of the remaining referees were as follows: Sh. Yuldashev $840 \mathrm{~m}, \mathrm{~F}$. Yuldashev $760 \mathrm{~m}, \mathrm{H}$. Nabiev, 740 m, O. Qosimov 640m, A.Abdullaev 840m, Z.Abduraxmonov 920m, M.Nexochin 920m $(66.2 \mathrm{~m})$. The analysis of the results revealed that the distance traveled by the assistant referees in the movement activity was almost half of the results of the chief referees.

Performance of the "Yo-Yo" test of different categories of assistant referees. Table 1.

\begin{tabular}{|c|c|c|}
\hline $\begin{array}{c}\text { Referees } \\
\text { Full name }\end{array}$ & categories & distance traveled \\
\hline B-v & 2 & 600 \\
\hline Y-v & 1 & 840 \\
\hline Y-v & 1 & 760 \\
\hline N-v & 2 & 740 \\
\hline K-v & 2 & 640 \\
\hline
\end{tabular}




\begin{tabular}{|c|c|c|}
\hline X-v & 2 & 620 \\
\hline T-v & 1 & 800 \\
\hline N-v & 1 & 700 \\
\hline A-v & 1 & 840 \\
\hline A-v & 1 & 920 \\
\hline R-n & 1 & 1040 \\
\hline
\end{tabular}

According to the analysis of the results obtained from the judges, it was observed that the results obtained were lower than the international standards. Only Nexochin $(1040 \mathrm{~m})$ and Abdurahmanov $(920 \mathrm{~m})$ showed slightly better results.

Theoretically, it should be noted that in the development of special endurance of assistant referees, it is necessary to take into account the characteristics of their movement activities, ie the creation and improvement of means of modeling game episodes. Because the way in which the loads are applied to the referees in the training sessions ensures that the same tools are used successfully in the episodes of the game, which are manifested in the form.

In conclusion, the results of tests on special endurance submitted by assistant referees of the 1 st and 2nd categories operating in our country are unsatisfactory, which leads to the problem of optimizing the exact norms and size and intensity of special endurance tools in the training programs of judges.

References.

1. Ўзбекистон Республикаси Президентининг 2019 йил 4 декабрдаги,, Ўзбекистонда футболни ривожлантиришни мутлақо янги босқичга олиб чиқиш чора-тадбирлари тўғрисида"ги ПФ5887-сонли Фармони. "Халқ сўзи” газетаси, 6 декабрь, 252сон

2.Соловьев, М.М. Мониторинг двигательной деятельности футбольных арбитров различной квалификации / М.М. Соловьев, А.В. Масленников // Лёгкая атлетика: сб. научно-методических трудов; НГУ им. П.Ф. Лесгафта, Санкт-Петербург. - СПб. :[б.и.], 2016. - С. 117-121.

3.Турбин Е.А. Выбор позиции и направления перемещения арбитрами в ходе игры / Е.А. Турбин // Теория и методика футбола. - 2004 г. - №2 - С. 14-18. 


\title{
THE ROLE OF THE USE OF FINE ARTS IN TEACHING THE HISTORY OF THE COUNTRY
}

\author{
Khaydarov Sulaymon Amirkulovich \\ E-mail: haydarov sulaymon82@mail.ru \\ Chirchik State Pedagogical Institute \\ Faculty of Humanities \\ 104, Amir Temur Street, Chirchik town, Tashkent region
}

\begin{abstract}
Annotation. This article discusses the compatibility of history with other disciplines in history textbooks, the analysis of historical positions in history textbooks, their didactic potential and their role and importance as an integral component of history education.
\end{abstract}

Key words: textbook, historical positions, didactic possibilities, dynasties.

One of the main subjects in educational institutions is the history of the Motherland. Because the student's attitude to national history is a set of skills and abilities that express his need to know the history of his people, national statehood. It is well known that history expands the scope of students 'mental knowledge with distant events that are beyond the scope of the present.

The student compares historical events, objects (objects, processes and events) in the environment with each other, and as a result identifies similarities and differences between them. In the process of historical thinking, the essence of historical facts is revealed through analysis and synthesis, and their important features or characteristics are clarified. Models, paintings, visual aids of historical monuments used in the study of history create the basis for a lively and effective transition to history. In addition, the use of historical sources as additional sources in history is more effective in conveying the topic to the reader. One of the effective tools of history lessons is works of fine art on a historical theme. One of the main subjects in educational institutions is the history of the Motherland. Because the student's attitude to national history is a set of skills and abilities that express his need to know the history of his people, national statehood. It is well known that history expands the scope of students 'mental knowledge with distant events that are beyond the scope of the present.

A prerequisite for the prevention of problems and shortcomings in the education of students is the establishment of a strong relationship between teacher and student. This requires the student to look at the subject of education as a person, not as an object of education. If the teacher does not take into account this methodological requirement, there will be an invisible "psychological barrier" between himself and the students, which will prevent them from understanding each other. The teacher must constantly work on himself to prevent such shortcomings in his work - to be constantly aware of the achievements of his subject, the methodology of teaching the subject, the advanced work experience of colleagues. In short, teaching activities should be based on collaborative pedagogy rather than authoritarian style. This is evidenced by the fact that in recent years, the "interactive methods of teaching" are rapidly entering the educational process.

The importance of using works of art on a historical theme in historical education is that they are distinguished by their authenticity and authenticity. After all, works of fine art on a historical theme are the main means of expressing a historical event with the unity of content, form, theme and idea.

Works of fine art reveal not only the external appearance of historical evidence and events, but also their inner essence. When using works of fine art on historical themes in the lessons of national history, it is necessary to pay attention to the following:

1.Live description of historical events that are planned to be studied in the program and textbook.

2.Demonstration of images of historical figures, representatives of the masses and the role of the masses.

3.Selection of fragments that help to embody the real landscape in the development of historical events.

During a history lesson, a work of art on a particular historical topic that relates to a particular topic should be explained not only in words but also by showing it to the students. Historical paintings differ in their nature, and the methodology of working on them also depends on it.

Philosophy, psychology, history, pedagogical sciences, in collaboration with the study of works of fine arts on historical themes, ensure the effectiveness of this process. In this case, the issue of organizing the mental activity of students is of great importance. Philosophical interpretation of works 
of fine art on the historical theme is the knowledge of events related to the history of the nation, the level of awareness of the material and spiritual world of the nation, its historically formed customs, traditions and values, religious, national identity, historical memory and its formation. consists of components such as the development of guidelines. These components are enriched by pedagogical tools, inculcated in the minds of students, theoretically and methodologically enrich the process of their study of works of fine art on historical themes.

As a result of adding a historical concept to a historical event in the process of teaching history, students will have the opportunity to understand its theoretical essence correctly and deeply. The concept evokes the imagination, which allows the student to explore the inner reaction to the event, the events, and prepares the ground for recording them. Imagination in these situations makes it possible to understand the general attitudes and connections of an object and a concept. Because students make a practical intellectual effort to master historical material. Moreover, historical concepts are formed as a basis, a source, a term in our minds of works of fine art on a historical subject. Mastering the science of history leads to the acquisition of historical terminology.

In short, works of fine art on a historical theme add clarity to the teaching material, concretize it, help to embody a complete and vivid picture of past and present life events in the eyes of students, perfect the system of their historical imagination, ensure teacher confidence and emotion. These factors ensure that students 'historical knowledge comes to life through visual aids.

References:

1.Boburnoma. - Toshkent: O‘qituvchi, 2008. -380 b.

2.Zaotov I. A. Izobrazitelnoye i dekorative -prikladnoye iskusstvo Krimskih tatar XX veka. Tashkent: Fan, 2001. - B. 120.

3.Oydinov N. O‘zbekiston tasviriy san’at tarixidan lavhalar. - O‘qituvchi, 1997. - B. 80.

4.Sharafiddin Ali Yazdiy. Zafarnoma. Movarounnahr voqealari. 1360-1370. - Toshkent: Kamalak, 1994. - B. 300.

5.Sharafiddin Ali Yazdiy. Zafarnoma. - Toshkent: Sharq, 1997. - B. 400.

6.С.А. Хайдаров. (2020). Ўзбекистон тарихини ўқитишда “Зафарнома”дан фойдаланишни имкониятлари. Science and Education. 1(7). 192-198

7.C.А. Хайдаров. (2020). Педагог-ўқитувчиларда ахборот-коммуникация кууникмасини шакллантириш асослари. "Science and Education." Scientific journal. 1(7). 610-617

8.Сулаймон Амирқулович Хайдаров. (2020). Тарих дарсларида интеграциялашган технологиялардан фойдаланиш. Science and Education. 1(8). 666-671

9.Хайдаров С. (2020). Ўзбекистон тарихи дарсларида педагогик технологияларни уйғунлашган холда қўллашнинг методик талаблари. Academic Research in Educational Sciences. 1 (3). 1313-1321.

10.Хайдаров Сулаймон Амирқулович. (2020). Тарих фанини ўқитишга оид экологик муаммолар масаласи «Scientific Progress» Scientific journal 1(1). 12-17.

11.Сулаймон Хайдаров. (2020). Ўзбекистон тарихи фани дарслари самарадорлигини оширишда тасвирий санъат воситаларининг роли. Science and Education, 1(6), 174-179.

12.С.А. Хайдаров. (2020). Тарих дарсларида тасвирий санъат асарларидан фойдаланиш. Science and Education. 1(9). 458-461. 


\title{
IMPROVING VOCABULARY USING EFFECTIVE LANGUAGE LEARNING STRATEGIES
}

\author{
Khudoykulova Dilnoza Zafarovna, \\ English teacher, 72-IDUM, \\ Chirchik district, Tashkent region
}

\begin{abstract}
Vocabulary is one of the three elements of language, the building material and the basic of language. To communicate with others fluently, the first premise is that we must have a certain amount of vocabularies. Facing so many words to learn, it's necessary to investigate the vocabulary leaning strategies. The paper mainly studies the strategies of vocabulary learning. Firstly, it introduces the importance of vocabulary learning and gives the definition and classification about the vocabulary learning strategies.
\end{abstract}

Keywords: vocabulary, social strategies, inadequate vocabulary, individual factors, effective intentional vocabulary instruction

All the words in a language make up what is generally known as its vocabulary. The term "vocabulary" is used in different senses. We also use it to refer to all the words of a given dialect, a given book, a given discipline and the words possessed by an individual person. Vocabulary learning as the foot-stone of the whole language learning, lays the foundation for students learning vocabulary and using various learning strategies rationally.

The role of vocabulary in learning a foreign language is inevitable. Rich vocabulary will totally help students mastering the language and its four major skills which cover listening, speaking, reading, and writing.

Mastering vocabulary means that students have comprehensive knowledge about the vocabularies which include the meanings, the spoken form, the written form, the grammatical behavior, the word derivation, the collocations of the words, the register of the word - spoken and written, the connotation or associations of the word, and word frequency.

The fact about perception above seems contradictive to another fact that vocabulary needs to be taught and learnt by applying effective strategies. Vocabulary teaching is aimed at enabling learners to understand the concepts of unfamiliar words, gain a greater number of words, and use words successfully for communicative purposes.

Concerning vocabulary learning stragety, Zarin and Khan (2014) investigating vocabulary learning strategies among undergraduate learners revealed that memory strategy was found as the most frequently used strategy whereas metacognitive strategy as the least frequently one. However, this finding is different from study of Kafipour and Naveh (2011) whose data gathered showed that students used metacognitive strategy most frequently and social strategies least frequently.

Departing from the description above and as an attempt to fill the gap, the present study was conducted to answer the following research questions:

1. How do teacher and students perceive vocabulary teaching and vocabulary learning?

2. What strategies are employed by teacher in vocabulary teaching?

3. What strategies are employed by students in vocabulary learning?

4. How do the vocabulary learning strategies employed by students influence their vocabulary mastery?

Vocabulary knowledge varies greatly among learners. The word knowledge gap between groups of students begins before they start their class. Why do some students have a richer, fuller vocabulary than some of their classmates?

- Language rich home with lots of verbal stimulation

- Wide background experiences

- $\quad$ Read to at home and at school

- Read a lot independently

- Early development of word consciousness

Why do some students have a limited, inadequate vocabulary compared to most of their classmates?

- Speaking/vocabulary not encouraged at home

- $\quad$ Limited experiences outside of home

- $\quad$ Limited exposure to books 
- Reluctant reader

- Second language - English language learners

The Importance of vocabulary learning in the trend of globalization, internationalization of language is unavoidable. Language will undoubtedly play the most important role. It includes three elements: pronunciation, vocabulary and grammar. It is obvious that vocabulary is the most essential and liveliest part of the three elements.

In vocabulary learning process we may face some factors. For example, in individual factors the differences between learners perform in several aspects, which include concepts, attitudes, personal emotion, and so on. The first point that the learners should pay attention to is their views about vocabulary learning. If the learner focuses on the vocabulary, they will be more use of cognitive strategies and memory strategies. If they pay attention to the function of the vocabulary, they will use fewer strategies such as cognitive, memory but more use of communicative strategies. And the age, learning motivation, character and personality differences of students and the differences of genders, also can influence vocabulary learning strategies. Moreover, the age of the learners and motivation also play important roles. Young learners tend to rely more on specific learning tasks to use strategies. However, adult learners can use strategies neatly. Adult learning strategies are more complex than children. They always use more learning strategies.

On the other hand, each student is an individual having their own living and growth environment, which formed a unique personality and individual differences. It also changes the different people's interests and needs. A research shows that most of the teachers and learners believe the personality factor plays an important role in foreign language learning. The different personality of students will have different degrees of influence on the English vocabulary learning. The researchers also found that some personality traits are related to the learner's strategies choice. Some researchers have proposed assumptions regarding the relationship between the usage of strategies and one's personality. They point out each character have the tendency of using some learning strategies.

In teaching process, we can use strategies like Incidental and Intentional Vocabulary Learning.

How do we close the gap for students who have limited or inadequate vocabularies? The National Reading Panel (2000) concluded that there is no single research-based method for developing vocabulary and closing the gap. From its analysis, the panel recommended using a variety of indirect (incidental) and direct (intentional) methods of vocabulary instruction.

When it comes to Incidental Vocabulary Learning, most students acquire vocabulary incidentally through indirect exposure to words at home and at school — by listening and talking, by listening to books read aloud to them, and by reading widely on their own.

The amount of reading is important to long-term vocabulary development. Extensive reading provides students with repeated or multiple exposures to words and is also one of the means by which students see vocabulary in rich contexts.

In Intentional Vocabulary Learning strategy students need to be explicitly taught methods for intentional vocabulary learning. According to Michael Graves (2000), effective intentional vocabulary instruction includes:

- Teaching specific words (rich, robust instruction) to support understanding of texts containing those words.

- $\quad$ Teaching word-learning strategies that students can use independently.

- Promoting the development of word consciousness and using word play activities to motivate and engage students in learning new words.

The meaning of a new word should be explained to students rather than just providing a dictionary definition for the word - which may be difficult for students to understand. According to Isabel Beck, two basic principles should be followed in developing student-friendly explanations or definitions:

- Characterize the word and how it is typically used.

- Explain the meaning using everyday language - language that is accessible and meaningful to the student.

For many students, it is easier to remember a word's meaning by making a quick sketch that connects the word to something personally meaningful to the student. The student applies each target word to a new, familiar context. The student does not have to spend a lot of time making a great drawing. The important thing is that the sketch makes sense and helps the student connect with the meaning of the word. 
Teachers can promote the development of word consciousness in many ways:

- Language categories: Students learn to make finer distinctions in their word choices if they understand the relationships among words, such as synonyms, antonyms, and homographs.

- Figurative language: The ability to deal with figures of speech is also a part of wordconsciousness. The most common figures of speech are similes, metaphors, and idioms.

References:

1.Beck, I. L., McKeown, M. G., \& Kucan, L. (2002). Bringing words to life. Robust vocabulary instruction, New York: Guilford Press.

2.Graves, M. F. (2006). The vocabulary book, New York: Teachers College Press, International Reading Association, National Council of Teachers of English.

3.The Use of Vocabulary Learning Strategies in Teaching Turkish as a Second Language, Sami BASKIN, Adem İŞCAN, Beytullah KARAGÖZ, Gülnur BİROL, Journal of Education and Practice www.iiste.org ISSN 2222-1735, Vol.8, No.9, 2017.

4.An Analysis of English Vocabulary Learning Strategies, Zhihong Bai, ISSN 1798-4769 Journal of Language Teaching and Research, Vol. 9, No. 4, pp. 853-859, July 2018. 


\title{
CONTENT AND SIGNIFICANCE OF “OPTICS" DEPARTMENT IN GENERAL SECONDARY EDUCATION PHYSICS
}

\author{
Kodirova Khamida \\ Freelance researcher at Andijan State University, Uzbekistan \\ e-mail: hamida1983@yandex.com
}

\begin{abstract}
Annotation: In this article, presents the results of studying the content and essence of the section "Optics" in the textbooks of a general secondary school, reveals the methodological features of its teaching, which contribute to the most effective assimilation of the necessary knowledge and skills by pupils. These sections consider the requirements for the level of training of pupils, compare the content of the section "Optics" at the interclass stages of school physics.
\end{abstract}

Key words: scientific programs, general education school, lighting phenomena, geometric optics, wave optics, quantum optics, optical conceptions

Systematic work is being carried out in our country to improve the quality and efficiency of the education system, the formation of modern knowledge and skills in kindergarten, schoolchildren and students, ensuring close cooperation and integration between education systems and science, continuity and continuity of education [1].

One of the most important topics studied in school physics textbooks is the topic of the "Optics" section. Indeed, the knowledge that students become acquainted with while studying this section can be applied by them in the future not only in vocational education based on the study of natural sciences, but also in the daily life and activities of each person.

However, the content of this section presented in the school physics course does not fully reflect the enormous importance of optics. Curricula today provide a wealth of information on this topic, but the methodology for presenting them requires significant improvement.

In line with the above, it is important to identify the specifics of learning the subject of "Optics" in school, to determine the methodological features of its teaching, contributing to the most effective acquisition of the necessary knowledge and skills by students. When students enter basic secondary education, the subject of "Natural Science" is generalized and considered as a science of physics, and they become acquainted with optical phenomena. In 6th grade, students begin to explore the "Light Incidents" section.

According to the "Curriculum of Physics of General Secondary Education", published by the Republican Education Center of the Ministry of Public Education of the Republic of Uzbekistan, the total number of hours (A1: 12, A1 +: 16) general level, A1 + - enhanced general level of physics study) [2]. In the process of learning science, students learn the basic concepts of light scattering, reflection and refraction of light, mirrors, spherical mirror imaging, flat mirror, lens, imaginary focus, focal length of the lens, optical power of the lens, lenses, optical instruments, the spectrum of light. In addition, in the process of studying this section, students acquire the skills of creating images, forming the ability to take different types of images: enlarged, reduced, inverted, direct, real, imaginary [3]. An important feature of the topic of "Light Phenomena" studied in the 6th grade physics textbook is that when students master it, they become acquainted only with the basic concepts derived from geometric optics, on the basis of which they continue to study in large classes. Forms ideas about the nature of light, its speed, knowledge of the spectral decay events of white light, and other issues related to the study of optical phenomena.

Preliminary information about light phenomena obtained in the lower grades is taught in more depth in the 9th grade of basic secondary education as a section "Optics". The program includes a total clock (A1:15, A1 +:22) in the "Optics" section. On the surface of the section, in 9th grade, students gain a broader and more comprehensive understanding of the laws of refraction and refraction of light, full internal reflection, convex and concave lenses, optical instruments, light dispersion, X-ray, photoelectric effect, and heliotechnics. At the same time, the ability and skill to determine the refractive index of glass, to create images using lenses [4].

Students in grades 6-9 will have the opportunity to learn about only two of the most important problems of the knowledge system about light phenomena during reading, namely, the behavior of light at the boundary between two environments and the properties of light propagation in the same environment. Based on the content of the material studied in basic high school, the content of this 
section can be considered as a combination of three main components: the distribution of light along a straight line, the laws of refraction and refraction of light, the phenomenon of complete internal return of light. All other materials that are familiar to basic secondary school students can be considered mainly as a result of the specified elements of the content [5].

By the 11th grade of secondary education, it will be possible to become acquainted with the theoretical understanding of the term "rays of light". Due to the simplicity of the laws of geometric optics considered during the reading period, experiments, as well as different forms and visual capabilities of the surrounding reality, students' cognitive activity further increases their interest in studying optical phenomena. Thus, the section "Electromagnetic waves and wave optics" will be taught in more depth. According to the curriculum, in the 11th grade, hours are allocated in the section "Electromagnetic waves and wave optics" (B1:15, B1 +:23). (B1 - general level of study of physics, astronomy, B1 + - enhanced general level of study of physics, astronomy) [6].

In the 11th grade physics classes of secondary education, the mastery of the topic "Geometric Optics" by the students is based on the knowledge they have acquired in the previous stage of education. In the process of studying this section in secondary education, students expand and deepen their already acquired knowledge about light phenomena, the nature and laws of light scattering. Moreover, at this stage, the attention of those studying optical phenomena is focused on aspects of the problem on this subject that have not only practical but also theoretical and methodological significance. As for the study of wave optics in secondary education, the greatest importance in its content is focused on the study of the phenomenon of interference of light, built on the ideas of interference phenomena of mechanical and electromagnetic waves, which already exist among schoolchildren. However, the diffraction of light waves is studied in detail in the context of this section, as its main task is to accurately prove the wave properties of light. Nevertheless, students 'understanding of light diffraction is also of great methodological importance due to the need to prove that geometric optics is a limiting phenomenon of wave optics. The study of the polarization phenomenon of light is also of great importance in the study of wave optics in high school. Its importance is determined by the fact that the study of the transverse nature of light waves is one of the most important conditions for reliably proving the electromagnetic nature of light. Knowing about the transverse nature of electromagnetic waves, in the process of studying the polarization of light, students answer a question about the nature of light waves.

In the 11th grade, the section "Quantum Physics" is devoted to teaching hours (B1: 4, B1 +: 6). In the section "Quantum Physics" topics such as the history of quantum physics, photoelectric effect, photons, photon momentum, light pressure, the application of the photoeffect in technology are studied [7].

An important element of the content of the "Optics" section in high school also becomes the introduction of students to the elements of quantum optics that occur at the end of mastering physics. That is, students will gain insights into the phenomenon of the photoelectric effect in quantum optics, photons, photon momentum, application of the photoelectric effect, light pressure, corpuscular-wave dualism of light, and the application of the photoelectric effect to technology. Effective organization of education at this stage requires a high level of development of abstract thinking in 11th grade students. The assimilation of quantum optics can be facilitated through the use of visual aids (pictures, tables, graphs, posters, photographs, animations, and multimedia products) in high school physics classes. Thus, it should be borne in mind that the study of the basics of quantum optics in school is a complex methodological problem, the specificity of which lies in the invisibility of the objects being studied and the complexity of the mathematical apparatus.

As a result of studying the "Optics" section, students should have the following knowledge and skills:

- understand the meaning of basic physical terms after graduating from basic school;

- to establish experiments on the study of light phenomena during the formation of the experimental task;

- to analyze the situations that have arisen in the course of practical activity, to use the knowledge of light phenomena studied in the process of their solution;

- Distinguish basic electromagnetic phenomena (linear propagation of light, refraction and refraction of light, scattering of light) and explain the main features of such phenomena using existing knowledge;

- use of optical circuits for imaging; 
- to analyze the objects and phenomena of the surrounding reality, applying knowledge of optical phenomena and their laws;

- solving problems using these laws.

Thus, the study of optics in general secondary education is of great importance for the formation of ideas in students about the role of experience in the cognitive process, the relationship between theory and practice, the infinity of the cognitive process. All this helps to form creative thinking and their subjectivity in school graduates. This, in turn, is due to the followers of Eastern scholars Abu Nasr Farobi, Abu Rayhan Beruni, Abu Ali Ibn Sino, Mirzo Ulugbek, Ali Kushchi and others, who contribute to the development of science and technology, able to withstand today's fierce global competition., leads to an increase in the number of young people committed to their profession.

\section{References}

1.Decree of the Republic of Uzbekistan "On measures for the development of education and science in the new period of development of Uzbekistan." - T .: November 6, 2020. OR No. PF-6108.

2.Curriculum of Physics of the Republican Education Center of the Ministry of Public Education of the Republic of Uzbekistan (grades 6-9). Tashkent -2017.

3.N. Sh. Turdiyev .N. Physics. Textbook for 6 th grade of general secondary education. Uzbekistan Publishing House. T: 2017 y. Page 132.

4.P.Habibullayev, A.Boydadayev, A.Baxramov, M.Yuldasheva. Physics. Textbook for 9th grade of general secondary education. Ghafur Gulom Publishing House. T: 2014 y. Page 81. 


\title{
USING THE METHOD OF COLORIFMICS IN TEACHING ENGLISH IN PRIMARY CLASSES
}

\author{
Madaminova Nilufar Madrasulovna \\ English teacher of the Academic lyceum of TSUL \\ +998-93-507-01-08 \\ bekoalik@mail.ru
}

\begin{abstract}
Annotation: This is an article about a method of teaching reading text with color study of rhymed endings and named as colorifmics. The method allows young learners of English to start reading as soon as possible, and immediately artistically.
\end{abstract}

Key words: colorifmics, intonation, division of words, recitative sounds, graphic image

The child learns to read by immediately hearing all the words in their entirety in the finished phrase and with the correct intonation (at first, as if playing reading). No syllable and letter-by-letter method, there is no "division of words"! Only the whole phrase, and with the correct intonation. Thanks to the method of colorifmics, children understand what they read well, are able to correctly intonate a phrase, placing logical accents in a sentence, which contributes to the formation of their fluent speech. What texts are being used according to the method of colorifmics? Lullabies, ballads, spirituals, poems, nursery rhymes, finger games. The main purpose of these songs and poems is to convey tenderness, care, affection, gaiety and slyness, anxiety and sadness. Music should draw a picture of the events that are sung in the song, thus connecting the language with the concept in the child's mind. And before each song, the recitative sounds its text in the form of a poem without separating individual words and syllables - this recitation is as close as possible to natural speech, a calm conversation between a mother and a child. This will help the child "grasp " the idea that the song conveys, and hold the related phrase while singing, without scattering it into separate notessyllables. Stages of acquaintance with the text for study on calorific:

passive listening image

representation based on drawings

finding consonant paired endings.

I've covered these stages in more detail below.

Phase one. The presentation of the song.

Presentation of the song, disclosure of its content. An adult translates the meaning of a song into concepts and visual images without having to translate it into their native language. You can use gestures, intonation, facial expressions, drawing or improvised means to represent phrase after phrase, and the child tries to guess what it is about.

Second stage. Listening to the song itself. Pinning an image (gesture) to the sound. We offer the child to "learn" certain situations that occur in the song and let him play them himself. For example, when it comes to the words "moon is peeking", the child finds the moon in the drawing, which looks out of the window, and on the words" Do you hear Sandman knocking "you can put your hand to your ear, as if listening, and then knock. Here, it would be very good to bring the child to the Arsenal of expressive means, in addition to drawings and gestures, he would also attract recitation, that is, he would try to imitate the voice of the announcer (or your voice) to depict events in the song, using as much as possible such a strong tool as intonation.

Third stage. Fixing the meaning and sound of a song with its graphic image. When the song is already "heard", and its meaning, explained by gestures and drawing, is fixed to the sound, you can proceed to the next stage - fixing the meaning and sound of the song with its graphic image, that is, with the text.

Catching words: following the text with your finger, the child shows the words that are currently playing in the song. Poetic song texts are so convenient for learning to read that each phrase of the song corresponds to a new line, and it is quite easy to" catch " it, track it with your finger. The process is similar to "reading from a sheet of music" in a symphony orchestra. (When" reading from a sheet", musicians do not actually" read " each note in the literal sense, but only follow the sequence of musical works based on the score). So the child, after listening to the song several times, almost remembers all of it by ear, but for smooth playback, he needs a "cheat sheet" in the form of familiar lines. 
Main stage. Selection of consonant percussive endings. Now that the intricate hooks on paper have become a little familiar to the child, you can start the main stage of colorifmics — to highlight consonant percussive endings. Different pairs of stressed syllables were painted in different colors. The child chooses the color for each pair at random!

This approach has a number of advantages. You don't need to fill your head with unnecessary information that is not related to the language. We do not impose any associations on the child, do not drive his own imagination into a rigid framework. The ability to choose colors independently makes the process more creative and interesting for the child. Teachers and parents who are interested in psychology will be interested in observing for themselves what color associations arise in a child.

So, let's summarize how we work with text on colorific.

First we tell the child about the story of the song in the language of images and gestures,

Then we turn on the song to the child, repeating the same images and gestures, but with singing and music.

Next, we present the text to the child and move his finger along the text (and then he himself). The child, singing along, will catch at first only the syllables that fall under stress, and the rest he will purr, passing mainly vowels.

And finally, we color the rhyming endings together with the child (and later he himself) in the color that he wants!

Literature

1.Ratz A. A. Fundamentals of color science and calorifics. Moscow. 2011

2.Nikitina N. L. Chromatics. The calorifics in the composition. S. Petersburg. 2015 


\title{
METHODS OF RESEARCH IN THE THEORY AND METHODOLOGY OF PHYSICAL EDUCATION
}

\author{
Tilavov Akbar \\ Teacher, Journalism and mass communication \\ University of Uzbekistan
}

\begin{abstract}
The article describes the theory and methodology of physical education by hard labor are one of the main profiling disciplines in the system of professional training of specialists with higher physical education. It is designed, through its content, to provide students with the necessary level of theoretical and methodological knowledge about the rational ways, methods and techniques of professional activity of a teacher of physical culture, to disclose in the structure and content of this activity the conditions for the successful implementation of educational, educational and recreational tasks of physical education.
\end{abstract}

Keywords: theory, methodology, physical education, professional activity, physical culture, methodological knowledge.

In the theory of physical education, as in most other scientific disciplines, two types of research are carried out $[3,64]$ :

1) actual-theoretical

2) experimental (including the setting of an experiment or the direct study of phenomena in natural conditions). For objective evaluation and analysis of the obtained results, methods of processing the obtained results (methods of mathematical statistics) are used.

Theoretical research proceeds in the form of logical operations (induction and deduction, logical and logical-mathematical modeling, analysis and synthesis, etc.), for which you need to have the actual material. It is drawn largely from literary and documentary sources. In this case, a number of special methods of analyzing and summarizing actual data are used.

Documentary materials include questionnaires and questionnaires specially compiled for scientific purposes. They differ from each other only in the volume of answers: in questionnaires, questions are posed in such a way that they answer them very briefly, for example, "yes" or "no"; in the questionnaire, answers are given in a detailed, descriptive form [2, 52].

Questionnaires and questionnaires are usually used for initial familiarization with the state of the matter.

Experimental methods or methods of pedagogical examination. This group includes methods for recording individual characteristics of the physical education process, not related to the intervention of the researcher in the course of this process $[1,69]$.

a) Pedagogical observation has distinctive features: a) the subject of observation is clearly indicated, b) a system for fixing observed facts (special protocols, notation conventions, etc.) has been developed.

b) Experimental methods. An experiment is a method of scientific research in which the phenomena and conditions of interest to the researcher are directly or indirectly under its influence and control.

From mathematical methods, the study of physical education studies the methods of mathematical statistics: correlation coefficient, rank correlation according to Spearman; factor analysis, $t$ is Student's criterion, etc.

As a rule, the research program has two sections - methodological and procedural [2, 74]:

The first includes the justification of the relevance of the topic, the formulation of the problem, the definition of the object and object, the goals and objectives of the study, the formulation of the main concepts (categorical apparatus), a preliminary system analysis of the object of the study and the presentation of a working hypothesis.

The second section describes the strategic plan of the study, as well as the plan and basic procedures for collecting and analyzing primary data.

In the theory of physical education, as in most other scientific disciplines, two types of research are carried out: actual-theoretical, and experimental (including the setting of an experiment or the direct study of phenomena in natural conditions). For objective evaluation and analysis of the obtained results, methods of processing the obtained results (methods of mathematical statistics) are used. 
A pedagogical experiment is an organized activity of a teacher-researcher and children with preset research goals. It includes a comprehensive method of scientific knowledge and relies on data from related sciences, requiring a certain pedagogical skill from the researcher. The success of the experiment depends on the theoretical and practical readiness of the researcher, his knowledge, interest in the intended problem, the ability to clearly define the goal, the thoughtfulness of the system and a serious understanding of the tasks.

Literature:

1.Menshikov, N.K. Gymnastics with teaching methods: Ed. N.K. Menshikov: Enlightenment, 1990.

2.Petrov, P.K. Methods of teaching acrobatic exercises and jumping at school: Textbook/P.K. Petrov, G.I. Ponomarev - Izhevsk: UdSU, 1994.

3.Smolevsky, V.M. Gymnastics and teaching methods: Ed. V.M. Smolevsky. - M.: F and C, 1987. 


\title{
THE PROBLEM BEAHAVIOURS AND WHAT TO DO ABOUT IT?
}

\author{
Khakimova Sadoqat Dilshodbekovna \\ Teacher, Uzbek State World Languages University \\ E-mail: Quyosh2017@inbox.ru
}

Annotation: The article describes issues related to the problems which appears while the lesson. As well, author expresses the firstly non-teacher related challenges as technical, no-student, no-register, no-room. Secondly teacher related problems are clarified as feel nervous, forgetting, nosy class, voice, unclear instruction. Students' behaviour which cause to the problem are the third part of the article. The researcher shares some alternative solutions to the discussed points.

Key words: teachers, students, problems, solution, group, behaviour.

Teacher should be open hard, kind and good listener and of course be ready the lessons. Even you do not let any question to the lesson some factors really influence to the quality of the lesson. 'Whether you're just starting or have taught for decades, teachers everywhere in the world are faced with similar challenges. The obstacles you encounter can arise from many directions: with students, parents, administrators, or with the many roles and responsibilities you have to maintain' ${ }^{1}$ Now we will talk some of them.

The problems appear while the lesson

1. Non-related to the teacher

One of the famous problems is no-teacher related issue. Nevertheless, the teacher ready the lesson, the class no suet to begin the lesson. It consists of some elements:

a) no-electricity - in this situation teacher should draw the presentation to the board while the explanation. (of course s/he do it if the presentation done by her/himself);

b) the computer breaks down - not only teacher but everyone should save their necessary documents to multiple place. The reliable one is our e-mail;

c) no any student - teacher should take at list monitor's phone number. The whole class is not be absent without any reason. Any way you should submit written apply to the administration;

d) no register of the group - before starting the lesson do not forget asking the register of the group. If it does not fined notes to your copybook and write notification to the administration. Dou to the theme and attendance is not mentioned, it means you do not teach your students;

e) No in the classroom your Students and another group of Students - sometimes the timetable is made by more than one person owing to several faculties or course. So that two groups come to the same class at the same time. Before start the lesson connect with the responsible person to you timetable.

2. Teacher related problems

Sometimes teacher do the best lesson plan and be ready to her/his lesson. But still exist some challenges:

a) feel nervous - teacher never be a sensitive without causeless so that you should find it and solve, if you can't solve it just give to the Solver and do your lesson confidently;

b) Forget necessary word - if your brain busy more than one questions you will lose concentration and it basis some unpleasant circumstances. When you have no anything to think over, please, check your blood pressure and your health;

c) the class is too nosey - there are some solutions as clap your hand, say 'keep calm' or 'keep silent' loader than usual, that wards are more effective if you are taking them all towards you and slowly lower both hands with the palms facing down;

d) students cannot hear the teachers voice clearly - teachers' voice should be loader than normal tone of voice. The first year of your teaching Ss will be you have that kind of issue. Often 2 or 3 lessons a pear day, unless you have some experience you can lose your voice. Please, do not drink cold or hot drinks, keep warm your throat. If you notes your tone of voice become poor not try to rise it at that time but keep silent and drink warm tea or coffee;

e) Students often have several questions after starting the task - if students cannot gain the teacher's instructions they give question either teacher or each other what to or how to do. We recommend,

${ }^{1}$ Adrien Dussault - Top 8 classroom challenges, according to teachers June 4, 2018 
invite one of the student to the board and give instruction to individual student. Than the student should give instruction to his/er friends. Listen carefully student's explanation, because you will use his/er way of sharing information the fallowing lessons

3. Students' behaviours which cause to the problem

Kindness is not solution for every question while the lesson. Ice-break technique is the best type of tool in order to start the first lesson, however not be so open hard, due to some students may ask from your boy/girlfriends till your income. The first lesson is the essential one, which you should create and put your classroom rules.

a) any way ill-behaved people tend to give out of topic question in the middle part of the lesson, even you are enough serious teacher - there are some alternative answers: the answer of your question is neither help you while the examination nor rest of your life; no out of topic questions, please; if you are really interest in my private life after the lesson ask your question not kill lesson's time; let's make speaking part and discuss this question with whole group...;

b) talks with other students - actually, you are hardly catch all students' attention everytime, so let SS talk and share their ideas with each other. If SS start chatting it means you should be gather their attention to the class, you may tell a jock or do another warm-up activity after it you can continue you lesson;

c) stay and walk in the class without asking permission - actually, adult learners rarely do this, but primary school pupils tend to do walk in the class. Again as a teacher you should be kind, so that, please, add action activities and tasks to your lesson plan. On the other hand if SS do not feel the lesson atmosphere their attitude not suitable the lesson. From entering to the class, please, great with $\mathrm{SS}$ and tell the lesson is begun;

d) call on students' parents in order to discuss your mark - in fact, it is good when parents interested their child's mark and teaching process, however, some of them do not interest the kids' knowledge but mark. If they call on or come to the class in order to discuss your assessing, please, tell them with polite tone ' $\mathrm{s} / \mathrm{he}$ is an individual person who has own barer and rights. Please, respect her/im, and let solve her/is problem herself/himself. I only discuss the mark with my student, not their parents.';

e) although your student do not proper it, one respectful person ask higher mark to him/her honestly, we live with people, that is way, sometimes respectful people ask higher mark than their proper. If it is happen the beginning part of the teaching process it is better. You can give enough tasks to the SS and help they fit the asked mark. Whereas, mainly the mark asked the ending part, which you can change nothing. There are some alternatives: politely explain the condition; give them additional task for some day and tell it is a last chance to them; the last one is, you should listen your soul and follow it;

f) some students late or not ready to the lesson regularly - call students after the lesson and speak with they, may be they have some problem. If they do not interest tell them 'person has no interest when they don't know the subject. Try to learn it, I will help you.' Stay your word and help them every lesson individually.

Thousands of issues will be appear the class before, while and after the lesson while your teacher career. Do not take it to your body as one illness but try to solve it on the way, there is no stress/ problem free profession.

We talk only problems but you forget all of them when your SS' growing, see their success, and bright their eyes when they understand something new for them. As our president mentioned 'Indeed, it is worth praising our hard-working and noble teachers, who instill in the hearts of millions of our children the knowledge of science and bring them up as worthy people of the country'2.

\section{The list of literature}

1. Adrien Dussault - Top 8 classroom challenges, according to teachers June 4, 2018

2. Uzreport.news Shavkat Mirziyoyevning O’qituvchi va murabbiylar kuniga bag'ishlangan tantanali marosimdagi nutqi. 30.09.20

${ }^{2}$ Uzreport.news Shavkat Mirziyoyevning O’qituvchi va murabbiylar kuniga bag'ishlangan tantanali marosimdagi nutqi. 30.09.20 


\section{PHILOLOGICAL SCIENCES}

PERSONAL THEORY AND INDIVIDUAL CHARACTERISTICS

Otabekhoja Sobitov,

Tashkent State Pedagogical University, 1st year student Phone: 90 959-56-07, E-mail: sobitov572@gmail.com

This article describes the personality and analyzes the views of scientists on the development of personality, the view of the newborn, the adult, the thinker, the mentally retarded, the savage, and the civilized countryman as an individual.

Keywords: person, individual, psychology, individuality, society, community, unity, science, problems, character.

The concept of "person" in psychology is broad and multifaceted. A person is a conscious individual who engages in some type of activity in a particular society and interacts with people through normal language ${ }^{1}$.

Man comes into the world as a man. The belonging of the subject to the human race is expressed in the concept of the individual. The child of an animal is called a creature from the day it is born until the end of its life. The concept of "individual" also includes a person's lineage. A newborn baby, an adult, a thinker, a mentally retarded savage, a savage, and a man of a civilized country can all be considered as individuals.

A person who is born as an individual discovers a special social quality, grows as a person. In psychology, the concept of personality is a set of social qualities that are formed by the individual in the process of practical activities and relationships, and determine the degree and quality of the impact of social relations on the individual.

What is a person? First of all, if we acknowledge that the individual is a quality of the individual, we are thereby affirming the unity of the individual and the individual and at the same time denying the similarity of these concepts.

A person who grows up outside of human society, when he first encounters people, cannot show that he has any personal qualities, which are always socio-historical in origin, apart from biologically specific individual characteristics, rather, the people around him will have only the natural conditions necessary for their emergence if they are able to "pull" him into the process of joint activity and interaction. The study of the experience of children raised among animals shows that the task is extremely complex.

Psychology "On the basis of what laws a person is subject to his inner world?" seeks solutions to problems such as ${ }^{2}$.

Each person's personality is composed only of his unique combination of qualities and attributes that make up his individuality. Individuality is a combination of psychological qualities that reflect its uniqueness, its difference from other people. Just as the concepts of "individual" and "person" are not similar to each other, in turn, the person and individuality form a unity, but they are not similar to each other. For a particular social unit, only the individual qualities that are more "involved" in the leading activity emerge as the particular qualities of the individual.

For example, dexterity and perseverance did not emerge as signs of a teenager's individuality, including as a characterizing character until he joined a team competing in a district championship in the sport or took on the task of crossing a fast and cold river during a tourist trip. That is why

\footnotetext{
${ }^{1}$ F.Khaydarov, N.Khalilova - General Psychology - T.:, 2009. Page 93

${ }^{2}$ NE.Goziev Higher school psychology - T .: "Teacher" 1997 - pages 104
} 
it is important to highlight the task of implementing an individual approach to the student, which is important for the educator. This requires taking into account the differential-psychological characteristics of the student (memory, attention, temperament, the development of this or that ability, etc.), that is, to determine how the student differs from his peers and how to organize educational work in this regard.

Around the person social, which is manifested in attitudes, collaborative and creative activities the ability to make significant changes is understood as the activity of the individual.

This is the word in his ideological principle, in his ability to defend his point of view appears in a vital position, which is expressed in the unity of work with. The study and understanding of the individual in Western psychology today The socalled "Humanitarian Psychology" - psychoanalytic (psychoanalysis) theories and views (the theory of existentialism of the individual - related to the idea of "survival", "subsistence", its proponents L.Binsvager, M. Boss, E. Minkovski, R. Mey, V. Frankl, Dj. Bugental vs.) are the most influential directions.

People change the world themselves, but consciously to participate in the construction of it, first of all, to change it it should be oriented that in the process of this work the person himself will also change. Modern scientific psychology is in the process of activating one's own activity and first of all, the rule that it manifests itself in the process of joint activity accepts. It directs and exists that directs a person's activity and activities a set of stable motives that are not related to situations is called personality orientation. Motives are more or less may be understood or not understood at all. Of the person the motives realized in the focus play a key role.

In conclusion, there is no doubt that the structure of the human personality is broader than the structure of the individual. Therefore, it manifests itself not only in the qualities and general structure, which show his individuality and is more widely expressed only in passion, appearance, abilities, etc., but also in interpersonal relationships, expressed in groups with different levels of development. must also be added. The individual typical feature manifests itself in significantly different ways depending on the nature, values and goals of the activity, which is an indirect expression of the development of the unit in which the person lives and is formed, and interpersonal relationships.

List of used literature:

1.F.Khaydarov, N.Khalilova - General Psychology - T.:, 2009. Page 93

2.E.Goziev Higher school psychology - T .: “Teacher" 1997. pages 104 


\title{
STATE AND LAW
}

\section{THE ROLE OF LEGISLATION IN ENSURING THE SUSTAINABLE DEVELOPMENT OF CITIES}

\author{
Guzal Uzakova Sharipovna, \\ Head of the Environmental Law Department \\ of Tashkent State University of Law, \\ $\mathrm{PhD}$, Associate Professor \\ E-mail: g.uzakova@tsul.uz
}

\begin{abstract}
The article describes the role of environmental legislation in the protection of the environment of settlements, especially cities, as well as legal issues of sustainable urban development.

Key words: settlement, sustainable development, environmental legislation, environmentally friendly environment
\end{abstract}

In the realization of the inalienable, inalienable human right to life, it is important to protect the environment of settlements, including cities, to choose the optimal forms of nature use in such areas, in short, to ensure the sustainable development of cities. According to the UN, the world's population will reach 7.8 billion in 2020 and will increase to more than 2 billion by $2050 .{ }^{3}$ The population of Africa and Asia is expected to increase significantly in the coming decades. More than half of the world's population lives in cities, and the number of urban agglomerations is growing. The UN estimates that by the middle of the 21 st century, the city's population will increase by an average of 200,000 a day, with seven out of ten living in urban areas ${ }^{4}$. In this case, more and more natural resources will be used for economic purposes, the amount of damage to the environment will increase, and the amount of land allocated for industrial, transport, energy and other economic purposes will increase.

It should be noted that the complexity of legal regulation in this area is that the law, on the one hand, should make the behavior of participants in environmental relations more acceptable to the urban population, on the other hand, address socio-economic problems identified in the forecast documents. The main environmental problems of cities to be solved are atmospheric air, water, soil pollution, noise effects, reduction of the size of the "green" area of cities and adjacent areas; lack of a unified state policy on environmental development of cities; striving to enlarge cities by creating megacities is a serious pressure on the environment and people; inconsistency (incompatibility) of the main (basic) functions of public administration to ensure the environmental quality of cities; such as the lack of a clear "environmentalization" of governance, such as spatial planning and urban zoning.

It is impossible to meet the diverse needs of people without taking into account the environmental requirements in the city. At the same time, the ecologically clean environment in the city creates opportunities for all-round human development. Man needs not only a psychologically healthy urban environment, but also an ecologically harmless environment, and the natural environment also requires careful treatment, creating the conditions to meet human needs. The principle of environmentally sound planning for the development and construction of urban areas is mainly reflected in the environmental requirements for spatial planning, urban zoning, construction of areas, environmental expertise, examination of project documentation, environmental regulation.

In this regard, one of the important conditions for sustainable development is to ensure the harmony of ecological, economic and social aspects of urban development. This principle forms the basis of environmental protection in cities. The basis of this principle is the idea of "sustainable

\footnotetext{
${ }^{3}$ www.countrymeters.info

${ }^{4}$ State of world's cities 2012/2013. Prosperity of Cities. United Nations Human Settlements Programme, 2012.
} 
development". In particular, the term "sustainable development", introduced by the United Nations Commission on International Environment and Development in 1987, refers to a development that meets current needs without compromising the ability of future generations to meet their own needs.

It is an environmentally sound economic and social development based on the idea of the mutual benefit of present and future generations. At the same time, many scientists link the emergence of the concept of sustainable development with the results of the UN Stockholm Conference on Human Environment (1972), which defined the general features of the relationship between environmental development and protection. Socio-economic and environmental problems of cities, growing urbanization, as well as participants of the UN Habitat III Conference on Housing and Sustainable Urban Development (October 17-20, 2016, Kyoto, Ecuador) were discussed. A new urban planning program (Kyoto Declaration on Environmentally Sustainable Cities and Settlements for All) has been adopted as part of the agenda (transparency, security, integrity and environmental sustainability of cities and towns) $)^{5}$.

In accordance with the implementation plan of the new UN Urban Development Program (Habitat III), it is necessary to create a comprehensive system of specific environmental and legal measures to be applied in planning the development and construction of urban areas within the concept of sustainable development. In particular, a number of factors must be taken into account when planning the development and construction of cities: the state of the environment (pressure on the environment in terms of physical, chemical, biological and natural components; accumulated damage in the environment and other factors); health status of the urban population (able-bodied and disabled; population by age groups) and its (population) level of education; type of cities and population; specialization of the city (priority sectors of the economy, science, technology or the possession of unique historical, cultural, etc. monuments in its territory); natural and geographical factors (ambient temperature, availability of water bodies, number of sunny or rainy days, the most common natural phenomena, including predictable, seismic activity of the area, flood zones, etc.); urban planning factors (nature of existing construction, characteristics of priority capital construction projects in the city, development of public places, street and road network system, etc.).

In short, ensuring the sustainable development of cities (settlements) is aimed at ensuring the harmonization of economic and environmental interests of society, in which environmental legislation plays an important role. 


\title{
SOME PROCEDURAL ISSUES OF THE INVESTIGATIVE ACTIONS AGAINST JUVENILE SUSPECTS AND ACCUSED
}

\author{
Nodirov Muzaffar \\ Deputy Dean for Youth Affairs, Faculty of Criminal Justice, \\ Tashkent State Law University \\ Phone: +998 (90) 3715022 \\ muzaf89@mail.ru
}

\begin{abstract}
: this article covers some of the procedural aspects of investigative actions against juvenile suspects and defendants. In particular, the issues of interrogation of juvenile suspects and accused and the reduced duration of the investigative action and other investigative actions are justified by the analysis of the legislation of developed foreign countries.
\end{abstract}

Key words: juvenile, suspect, accused, interrogation period, investigative actions.

One of the necessary conditions for the inquiry and preliminary investigation in criminal proceedings is the investigative action. Investigative actions also appear to be an important means of gathering evidence in juvenile criminal cases. In this regard, it is important to ensure that the rights and legitimate interests of minors are respected in the conduct of investigative actions.

As Chernetsova noted, the investigative actions against minors are specific, with priority given to the observance and protection of the rights and legitimate interests of minors. The specificity of the investigative action against a minor is due to the special procedural status of this person in criminal proceedings ${ }^{6}$.

Indeed, due to the intellectual, mental, physiological and other characteristics of the juvenile, investigative actions involving this category of person are required to have specific characteristics. These specifications are defined primarily as additional guarantees aimed at ensuring the rights of the minor. However, the current Code of Criminal Procedure of the Republic of Uzbekistan specifies the specifics of conducting investigative actions with the participation of a minor only in relation to the investigative action of interrogation. The law does not provide for a special procedure for other investigative actions involving this category of persons.

Below, by analyzing the investigative action of interrogation of a minor, we will consider the introduction of special rules for the implementation of other investigative actions provided for in the Code of Criminal Procedure with the participation of a juvenile suspect, accused.

An interrogation is an investigative act aimed at obtaining instructions from a person who has information that is relevant to the case. The purpose of the interrogation is to obtain complete and reliable information about the circumstances that are relevant to the subject of the evidence and are important for the proper investigation, review and resolution of the case. The purpose of the interrogation may also be to examine the available evidence ${ }^{7}$.

According to SI Koloskova, the information obtained from the juvenile directly during the interrogation is a full and comprehensive study of his identity, motives for committing a crime, the mechanism of criminal behavior; to determine whether the minor was affected by adults, his living and upbringing conditions; identification of mitigating and aggravating circumstances that exclude the criminality of the act, and thus strictly individualize the measure of criminal law applied to a minor ${ }^{8}$.

According to Article 553 of the Code of Criminal Procedure of the Republic of Uzbekistan, the interrogation of a minor suspect and accused shall be carried out in the presence of a defense counsel, legal representative. The defense counsel and legal representative have the right to ask questions to the suspect and the accused. Upon completion of the interrogation, the defense counsel and the legal representative have the right to review the statement and express their views on it. The total duration of the interrogation of a juvenile suspect or accused shall not exceed six hours, excluding an one-hour break for rest and meals during the day. Accordingly, the legislation of many states sets a shorter time for interrogation of minors than for adults. Including the criminal procedure legislation of the Republic 
of Kazakhstan ${ }^{9}$, Moldova ${ }^{10}$, the republic of Kyrgyz ${ }^{11}$, the Republic of Tajikistan ${ }^{12}$, the Republic of Turkmanistan ${ }^{13}$, the Republic of Belarus ${ }^{14}$, Russian Federation ${ }^{15}$ stipulates that interrogation of a juvenile suspect or accused shall be conducted during the day and shall not exceed two hours without interruption.

Based on the above, we believe that it is appropriate to reduce the duration of the interrogation in order to ensure more effective observance of the rights and interests of minors during the interrogation process.

\footnotetext{
9 The Criminal Procedure Code of the Republic of Kazakhstan dated July 4, 2014 No. 231-V. // http://online.zakon.kz

${ }^{10}$ Criminal Procedure Code of the Republic of Moldova dated March 14, 2003 No. 122-XV. http://continent-online.com/ Document/?doc_id=30397729

${ }^{11}$ Criminal Procedure Code of the Kyrgyz Republic dated February 2, 2017 No. 20. http://cbd.minjust.gov.kg/act/view/ru-ru/111530

12 The Criminal Procedure Code of the Republic of Tajikistan dated December 3, 2009 No. 564. http://continent-online.com/ Document/?doc_id=30414857

${ }_{13}$ Criminal Procedure Code of Turkmenistan dated April 18, 2009. // http://www.turkmenbusiness.org/node/124

${ }^{14}$ Criminal Procedure Code of the Republic of Belarus dated July 16, 1999 No. 295-3. http://kodeksy.by/ugolovno-processualnyykodeks

${ }^{15}$ The Criminal Procedure Code of the Russian Federation of December 18, 2001 No. 174-FZ. // http://www.consultant.ru/ document
} 
THE CONSTITUTION IS A GUARANTEE OF HUMAN RIGHTS AND FREEDOMS

\author{
Raximova Ilmira Marksovna \\ Teacher of Khorezm regional school of law \\ Artikova Ugiljon Umid kizi, \\ Baxtiyarov Jumaniyoz Ixtiyor ugli \\ Students of Khorezm regional school of law
}

\begin{abstract}
Annotation: In this article the rights and freedoms of the people are clearly described and analyzed in number of articles of the Constitution. The guarantee of human rights are given with examples.

Key words: human rights, freedom, article, guarantee, reform, honor, value.
\end{abstract}

Over the past years, our country has carried out large-scale reforms aimed at reliable protection of human rights. First of all, the Constitution of the Republic of Uzbekistan states that one of the most important provisions of the principle of people's power is the supreme value of man, his life, freedom, honor, dignity and other inalienable rights (Article 13).

A guarantee is a set of tools, methods and conditions that help the state to ensure the implementation of the rights and freedoms of citizens enshrined in the Constitution and laws. Within the framework of this constitutional principle, Chapters 7-9 of our Basic Law define the personal, political, economic and social rights, freedoms and guarantees of man and citizens. Today, a free civil society is being built in Uzbekistan and a humane democratic state governed by the rule of law is being built. Democratic rights and freedoms are protected by the Constitution and laws. Human rights and freedoms are guaranteed not only by the norms of the national Constitution, but also by the universally recognized principles and norms of international law recognized by the world community. The main goal of the Constitution of Uzbekistan is to build a free civil society, i.e. a society directly governed by the people and a humane democratic state governed by the rule of law. The idea that the greatest of all worldly blessings is "man" is embodied in this rule.

The glorification of man, his protection and all-round perfection have become the main idea of the Constitution. Our Constitution is based on international human rights law and can be said to have supplemented it. For example, Article 13 of the Constitution proves our point. In this article, the universal human rights enshrined in the Universal Declaration of Human Rights have been elevated to the highest level. It is well known that the Universal Declaration of Human Rights proclaims the inalienable and inviolable rights of human beings, stating: "All human beings are born free, equal in dignity and rights" (Article 1); "Everyone has the right to life, liberty and security of person" (Article 3); "No one shall be held in slavery or servitude, and all forms of slavery and the slave trade shall be prohibited" (Article 4), etc. Article 13 of our Constitution states that a person, his life, freedom, honor, dignity and other inalienable rights are of the highest value. This shows that Uzbekistan is a country based on universal humanitarian principles. There are no restrictions on human rights in Uzbekistan based on ethnicity, religion, social status, political or other beliefs. In particular, the second section, which is one of the most important parts of the Constitution, is devoted to the fundamental rights, freedoms and duties of man and citizen. One of the peculiarities of the High Document is that it strengthens the sacred and inviolable rights not only of citizens, that is, of those who belong to our state, but of all people living in Uzbekistan. No one other than the law can deprive him of his rights.

The activity of any state body in the Republic of Uzbekistan is aimed at serving and improving the well-being of man and society. The state must uphold social justice and the rule of law as it carries out its function through its appropriate bodies. One of the most important conditions of a democratic state governed by the rule of law is the supremacy of the interests of man and the individual over all else. The principle of legality means, first of all, those laws and other legal acts adopted on its basis must be clearly and unequivocally complied with by state bodies, officials and citizens. The principle of legality means that laws have the highest power in the system of legal documents, are equal for all, and are binding on all members of society.In the state policy on human rights, the issue of the fact that human rights and freedoms can be realized only after strengthening them in society on the basis of legislation and providing them with a system of economic, political, legal, organizational guarantees. According to Article 43 of the Constitution, the State guarantees the rights and freedoms of citizens enshrined in the Constitution and laws. The main task of the state is to ensure rights and freedoms. To this end, the creation of legislation by the state to ensure rights and freedoms, the establishment of a 
system of bodies ensuring rights and freedoms is an activity aimed at ensuring rights and freedoms. Public authorities in all branches of government have the task and authority to ensure the rights and freedoms of citizens. The most basic and effective means of ensuring the rights and freedoms of citizens in a state governed by the rule of law is the provision of rights and freedoms by the courts. In order to protect the needy, Article 45 of the Constitution stipulates that the rights of citizens in need of protection are protected by the state. The content of this article is that minors, the disabled (various categories of disabled people) and the lonely elderly, in addition to enjoying all rights and freedoms, in addition, their rights are under special protection of the state. As mentioned earlier, Article 18 of the Constitution establishes equality before the law regardless of gender, while Article 46 of the Constitution states that "men and women have equal rights" and guarantees equality in all spheres. Numerous legal documents have been adopted and measures have been enacted to ensure the equal rights of women and men in practice. This guarantees equality before the law in relations between members of society, regardless of gender. It also regulates their vital relationships.

The Constitution of the Republic of Uzbekistan serves as a guarantee of protection of human rights and freedoms from violations by anyone. Universal values, such as human rights and democracy, are fully consistent with the interests of the national statehood of our republic.

Bibliography:

1.The Constitution of Uzbekistan. Tashkent, Uzbekistan, 2012.

2.The National Encyclopedia. Tashkent, Uzbekistan, 2000-2005

3.www.ziyo.uz 


\title{
SOME ASPECTS OF UZBEKISTAN'S APPROACHES TO ENSURING FOOD SECURITY IN THE CONTEXT OF COUNTERING THE COVID-19 CRISIS
}

\section{Rukhshona Madalieva Hakimdzhanovna, Customs Institute, Ph.D.}

\begin{abstract}
This article is devoted to the consecration of the issues of ensuring food security in Uzbekistan during the fight against Covid-19. In particular, specific measures are considered to support the food market, social support of the population, as well as to ensure the continuity of food supplies with the countries of Central Asia in the context of a pandemic.

Key word: Food, food security, Covid-19 pandemic, agriculture, social assistance, government support, food supply chains.
\end{abstract}

2020 has become a real test for humanity. The rapid spread of the coronavirus infection has brought about fundamental changes in the trade and economic relations between the countries that have been dynamically developing up to this time in a certain format. The forced, due to quarantine, the closure of borders, the temporary suspension of cross-border transport movements, the restriction of cargo transportation had a tangible impact on the spheres of food supply and production. However, despite the complexity of this period, the international community continues to hold on to a close bond of cooperation.

In Uzbekistan, from the very first days of the detection of the virus, enhanced measures were taken to counter the spread of the disease and protect the health of the population. The resources of the state are directed as much as possible to provide polyclinics, hospitals and health-improving institutions with the necessary medicines and medical equipment, to provide targeted social protection to the population, and state support to various sectors of the economy and business.

The head of our state Sh.Mirziyoyev noted the importance of "... consolidating the efforts of governments, parliaments and civil society, strengthening the principles of shared responsibility, close coordination in developing international partnerships, raising the status and potential of the World Health Organization and expanding its powers" [1].

Uzbekistan has always supported active cooperation with the UN in the implementation of the concept of sustainable development. To replace the Millennium Development Goals in September 2015, New York adopted a sustainable development agenda entitled "Transforming Our World: The 2030 Agenda for Sustainable Development".

At the one hundred and sixty-fourth FAO (World Food and Agriculture Organization of the United Nations) Session on June 6-10, 2020, dedicated to the "Implications of the Covid-19 pandemic for food security and food systems", a Covid-19 threat assessment for food security and nutrition was carried out. The FAO session concluded that, in contrast to the 2007-2008 food crisis, the problem today is not food availability, but access to it. As an effective response to the pandemic, FAO encourages countries to continue to make every possible effort to keep their food supply chains operational. [2]

FAO experts identify four principles as the basis for ensuring food security, which are:

- availability of food;

- access to food;

- the use of food;

- stability.

Food security is an integral part of the national security of a nation, the concept of which, according to the Declaration of the World Summit on Food Security, adopted in November 2009 in Rome, is to ensure that all people have physical, social and economic access to sufficient safe and nutritious food to maintain an active and healthy life.

Already in the first half of 2020, the pandemic, and the related strict isolation quarantine measures, initially had a serious impact on various areas of socio-economic development. The Government of Uzbekistan has identified priority tasks to support the population and its most vulnerable strata by providing material support and food security.

Based on the current situation that affected the whole world, President Mirziyoyev, in his video address to the UN General Assembly on September 23, 2020, proposed to support the position of UN Secretary General António Guterres on holding a summit on topical issues of food security in the context of the ongoing crisis.

An effective impetus in overcoming the impact of the pandemic in Uzbekistan was the timely 
adoption of individual measures and decisions to minimize the negative impact of the crisis on the food and agricultural sectors of the economy.

On May 1, 2020, the Resolution of the President of the Republic of Uzbekistan PP-4700 "On measures to ensure food security, rational use of available resources and state support for agriculture during the coronavirus pandemic" was adopted. The document identifies concrete effective measures for the fullest use of available resources and opportunities of agriculture, doubling food crops, obtaining a high harvest, introducing modern approaches to creating new jobs and increasing interest in the agricultural sector in the face of the risk of food shortages in the world ... The "Roadmap" was approved for the consistent implementation of the tasks set.

As you know, the land has played a significant role in the life of the people of Uzbekistan since ancient times. The opportunity to work on it and benefit from its results, strengthens the sense of the owner, increases responsibility and incentive for further cultivation and development of agricultural activities.

Based on this, in our opinion, one of the effective measures approved in the above document is the decision to lease out land plots put into circulation, primarily to families in need of social protection and low-income families with knowledge and skills in the industry. agriculture for dekhkan farming up to 1 hectare. Establishing the activities of 74 family cooperatives in the direction of animal husbandry in the Republic of Karakalpakstan, Bukhara, Jizzakh, Kashkadarya, Navoi, Surkhandarya and Syrdarya regions [3].

Measures for state support of the population with food and goods, taken by Uzbekistan for the healthy functioning of society, during the Covid-19 crisis, have received a worthy assessment from international structures. In particular, from the point of view of FAO experts in Uzbekistan, the pandemic has not yet led to significant disruptions in agriculture. The government is taking all necessary measures to ensure that the spring sowing campaign is successful, the new harvest of fruits and vegetables can reach consumers without hindrance, and industry workers can relatively freely get to their jobs.

At the very beginning of the quarantine measures, the local market reacted to the pandemic panic by raising food prices. However, prices for their main types, for example, wheat and flour, today, if increased, are not significant. In addition, as you can see, the shelves of shops and the counters of bazaars are filled with products, points of sale of food products are opening in makhallas, and many sellers offer home delivery of products. Of course, it cannot be ruled out that in some regions of the country a temporary shortage of certain types of food is possible, but local authorities are taking fairly prompt measures to resolve this issue [4].

The foreign economic policy of Uzbekistan is closely linked with the countries of Central Asia, in the GDP and export potential of which agriculture occupies a significant place. Support for this direction is one of the priorities in the activities of the World Bank in Central Asia. With the assistance of an international structure, projects totaling about 1.6 billion US dollars are being implemented in the region, most of which are aimed at modernizing agriculture. Thus, the World Bank provided Central Asia with $\$ 370$ million to support the economy and population during the fight against coronavirus. Most of these funds - 312 million were received by Uzbekistan: 95 million to improve the national health system and support the poor, 200 million to provide the budget with additional funds, 17 million to improve the emergency medical care system [5].

Among the problems associated with measures to ensure food security and agricultural development during the coronavirus pandemic, key attention is paid to maintaining continuous communication between the countries of Central Asia on measures aimed at avoiding disruptions in the integrity of the infrastructure of the food market and the food distribution chain.

The infrastructure of the food market is understood as a set of organizations involved in promoting the flow of goods, from the moment of production to final consumption, and the system of relationships between them, which should support the continuity of the chain from the producer to the final consumer [6].

Thus, objectively assessing the risks of the impact of the coronavirus pandemic on the country's economy, in Uzbekistan, one of the main tasks remains to maintain the quality of life of the population, by ensuring the availability and sufficiency of food, replenishing the consumer market with food and reasonably coordinating prices for them. 
References:

1.From the speech of the President of the Republic of Uzbekistan Shavkat Mirziyoyev at the 75th session of the General Assembly of the United Nations // https://president.uz/ru/lists/view/3851

2.COVID-19 and the risk to food supply chains: what to do? // http://www.fao.org/3/ca8388ru/ CA8388RU.pdf

3.Resolution of the President of the Republic of Uzbekistan PP-4700 of 05/01/2020 "On measures to ensure food security, rational use of available resources and state support for agriculture during the coronavirus pandemic" // https://lex.uz/ru/docs/4803525

4.Agriculture and food security in a pandemic. // https://www.gazeta.uz/ru/2020/04/20/agriculture/

5. What difficulties does the food market of Uzbekistan face against the backdrop of a pandemic? // https://forbes.uz/process/exp ertise / ekspertyi_vsemirnogo_banka_obsudili_prodovolstvennuyu_ bezopasnost_v_tsentralnoy_azii /

6.T. Vorozheikina. Strategic development of the commodity distribution infrastructure of the food market. // Agroengineering. No. 3, 2013. P.-72 


\title{
TECHNOLOGICAL SCIENCES
}

\section{INTERNATIONAL EXPERIENCE IN TECHNICAL REGULATION AND PRODUCT SAFETY}

\author{
Parahat Mailievna Matyakubova ${ }^{1}$, \\ Nuriddin Anvarovich Abdujabarov ${ }^{2}$, \\ Mirolim Muhammad o'g'li Mahmudjonov', \\ Gulomjon Ibodullaevich Avazov ${ }^{4}$ \\ ${ }^{1}$ Tashkent State Technical University, the DSc. \\ Tech., professor of chair "Metrology, standardization and \\ certification" department, Tashkent city 100 095, Uzbekistan, \\ E-mail: tgtu_mss@rambler.ru \\ ${ }^{2}$ Tashkent State Transport University, \\ Ass.professor, "Aviation engineering" department \\ Tashkent city 100 011, Uzbekistan \\ ${ }^{3,4}$ Tashkent State Technical University, assistant of \\ "Metrology, standardization and certification" department, \\ Tashkent city 100 095, Uzbekistan, \\ E-mail: mirolim.muhammad.92@gmail.com
}

\begin{abstract}
The paper considers the issues of the system of technical regulation and standardization of product quality and safety and the environment in the EU countries, which, in comparison with the systems operating in the USA, have both general principles and specific features. The general relationship between mandatory and voluntary standardization is analyzed.

Key words: Regulation, standard, safety, adaptation, mechanical safety, chemical safety, biological safety, structure, operation.

Within the framework of the international project Erasmus + "New study program in space systems and communications engineering", the creation of textbooks, educational and methodological aids, as well as the study of the safety of aerospace equipment, tasks are being carried out to study and improve standards and technical regulations to ensure the safety of products. Meeting the needs of society with high quality products that meet all the requirements for its safety, and maintaining the proper quality of the natural environment is the goal that faces the Republic of Uzbekistan, Russia, the United States, Western European countries and the entire world community. But they go to it as if from different starting points.

USA transitioned from classical capitalism, the maximum free market to a regulated socially oriented market economy, while Russia - from a socialist state-planned economy to the creation of an effective market economy, at the same time maintaining the necessary government levers and ensuring effective social protection of citizens.

The peculiarities of the economic model of the European Union and, accordingly, its technical and environmental policy are due to the fact that it combines various groups of countries.

The European Union has to solve serious problems in the process of building a single economic, political and legal space, developing a common policy in all spheres of society and, accordingly, unifying legislation.

Technical regulation. This concept was introduced into the legislation by the Law "On Technical Regulation". In connection with the adoption of this law, the existing Law of the Republic of Uzbekistan "On standardization" of December 28, 1993 was declared invalid.
\end{abstract}


Entrepreneurial activity is part of economic activity. It is carried out in accordance with the state economic policy, enshrined in legislative and other normative acts. The legal basis for entrepreneurial activity is a system of regulatory support and a legal mechanism for the implementation of legal norms governing production and economic activities.

Technical regulation, or, in other words, normative and technical regulation is an integral part of the legal regulation system both in the field of entrepreneurship and in other spheres of the economic and social life of society.

When starting to study the problem of technical regulation of the quality and safety of products and the environment, it is necessary first of all to define such categories as "product quality", "environmental quality", "product safety", "environmental safety", "technical regulation" and "standardization", "technical regulations", "standard" and "normative and technical documentation", since in domestic and foreign literature, as well as in the legislation of the Republic of Uzbekistan, the United States and the EU countries, their different interpretations are often given, which creates certain difficulties in lawmaking activity, in the practice of applying legal norms and is the subject of constant discussions in the legal literature, especially Russian.

Product quality. Product quality as a category and concept can be viewed in three aspects: philosophical, technical and economic and legal.

Hegel gives the following definition of quality as a philosophical category: "Quality is, in general, an immediate determination identical with being ..." "Something is, thanks to its quality, what it is and, losing its quality, it ceases to be what it is ..." [2]

Consequently, in a philosophical understanding, product quality is a set of properties of a product that characterizes its essential certainty, due to which it is a given, and not another product. In this sense, any product, even the worst product, has some quality.

The technical and economic concept of "product quality" covers those properties that are associated with the satisfaction of certain social or personal needs in accordance with its purpose. This interpretation of product quality is given in the standards and in special literature.

In the ГОСТ 15467-79 standard, quality is a combination of product properties that determine its suitability to meet certain needs in accordance with its purpose.

In ISO 8402-86, quality is the collection of properties and characteristics of a product that give it the ability to meet determined or implied needs. In the O'z DSt ISO ISO 9000: 2015 standard, quality is the degree to which a set of inherent characteristics meet a requirement.

Product quality is a set of properties and characteristics that are objectively inherent in a product, the level or variant of which is formed when creating products in order to meet existing needs. The latter definition seems to be the most successful definition of quality product as a technical and economic category. It emphasizes both objective factors that characterize the essence, certainty of a particular product, and subjective - the degree of compliance with needs, that is, utility.

In accordance with the Law of the Republic of Uzbekistan "On technical regulation" dated April 23, 2009 No. 3PY-213 (with subsequent amendments and additions), not all indicators of product quality are now subject to state regulation of this kind, but only requirements for its safety. The consumer properties of products are the sphere of voluntary technical regulation in the form of voluntary (recommendatory) standards.

The reference to him in the contract means that his claims become part of the contractual obligations. By their legal nature, such standards are also normative legal acts, which are usually called local. After their adoption on a voluntary basis, in order to fulfill contractual obligations, they are approved as a standard of the enterprise (organization) by its management and are obligatory for the relevant departments and services of the enterprise (organization).

Safety of products, works and services. The legal definition of this concept is given in the Law "On Technical Regulation": "... the state of products, processes of their production, operation (use), storage, transportation, sale and disposal, work performed, services provided, in which there is no unacceptable risk associated with the probability causing harm to life, human health, the environment, property of legal entities, individuals and the state".

Product safety criterion is the absence of unacceptable risk at all stages of its life cycle, that is, creation, production, consumption, operation, transportation, storage, processing, disposal.

Objects of protection from the dangerous effects of products: life and health of people; property of citizens and legal entities; state and municipal property; natural environment, including fauna and flora. 
The quality of the environment. Globalization has given rise to an environmental crisis, overcoming which is one of the urgent tasks of the world community and, accordingly, international and national law.

The environment is a set of components of the natural environment, natural and naturalanthropogenic objects. Its components include the earth, bowels, soils, underground and surface waters, atmospheric air, flora, fauna and other organisms, as well as the ozone layer of the atmosphere and near-earth space, which together provide favorable conditions for the existence of life on Earth.

A natural object is a natural ecological system, a natural landscape and their constituent elements, which have preserved their natural properties. A natural-anthropogenic object is a natural object changed as a result of economic and other activities, and (or) an object created by man, possessing the properties of a natural object and having recreational and protective significance. In contrast, an anthropogenic object is an object created by man to meet his social needs and does not possess the properties of natural objects.

When defining the concept of "environmental quality", it is necessary to bring its distinction with the concept of "favorable environment" and to understand the meaning of the concept of "negative impact on the environment".

In the literature, these three definitions are formulated as follows.

The quality of the environment is the degree to which natural conditions correspond to human physiological capabilities. Distinguish between healthy or comfortable natural environment, in which a person's health is normal, and unhealthy, in which the state of health is impaired.

Favorable environment - an environment whose quality ensures the sustainable functioning of natural ecological systems, natural and natural-anthropogenic objects.

Negative environmental impact - the impact of economic and other activities, the consequences of which lead to negative changes in the quality of the environment.

The above definitions, in our opinion, do not sufficiently reveal the key concepts in the sense that they "do not work" in the legal norms of the law and are perceived as provisions of a general educational, declarative nature. They do not have any legal meaning, and there is simply no need for such definitions in legislative acts.

Determination of the negative impact on the environment is a tautology, does not provide any additional information and from a legal point of view it makes no sense, since the border between what is permitted and what is not allowed is not drawn, without which it is impossible to impose on an economic entity - a natural resource user the obligation to restore the quality of the environment, as well as qualify his actions (inaction) as an environmental offense.

\section{List of references}

1.Legal assurance of the quality and safety of goods: theory and practice. Monograph. - M.: Prospect, 2020.

2.The Civil Code of the Russian Federation. Text, comments, alphabetic subject index / ed. O. M. Kozar, A. L. Makovsky, S. A. Khokhlova. - M.: Spark, 2004. - 704 p.

3.Law "On Protection of Consumer Rights". M.: UNITY-DANA, 2002.

4.Alekseev S.S. Right. ABC. Theory. Philosophy. Comprehensive research experience. - M., 1999

5.Ershova IV, Ivanova TM Entrepreneurial law: textbook. -M.: Jurisprudence, 2002. - 540 p. 


\title{
CULTUROLOGY
}

\begin{abstract}
International scientific and practical conferenceCUTTING EDGE-SCIENCE, USA PROBLEMS FOR THE APPLICATION OF INTERACTIVE LEARNING IN MUSIC ART LESSONS IN PRIMARY SCHOOL
\end{abstract}

\author{
Stukalenko Z. M. \\ Central Ukrainian State Pedagogical \\ Volodymyr Vynnychenko University, \\ Candidate of Pedagogical Sciences, Senior \\ Lecturer of the Department of Music Art and \\ Methods of Music Education
}

Keywords: interactive learning, music teacher, elementary school, methods, technology, music art, lesson.

Today, it is extremely important to update the educational process, adapt it to European and world standards, and therefore the use of innovative technologies is not just a "tribute to fashion", but a necessary, extremely important factor in the growth and development of Ukrainian education and, consequently, society as a whole. Music lesson as the main form of educational process includes various types of musical activities of students. A special emotional atmosphere is characteristic of music lessons. After all, music is a language of feelings. V. Andrushchenko, I. Zyazyun, V. Kremin, V. Luhovy, A. Nisimchuk, O. Sukhomlynska, V. Shadrikov, O. Padalka, O. Shpak devoted their works to the problems of innovative technologies. The very concept of "technology" comes from two Greek words - "art, skill" and "word, learning". Thus, technology can be defined as a conscious practical art, a conscious skill. Modern researchers believe that any pedagogical technology must meet some basic methodological requirements, or rather - the criteria of manufacturability. T. Zakharchuk defines them, in particular, as follows: conceptuality, system, controllability, efficiency, reproducibility, visualization [2]. "A feature of interactive learning is the preparation of students for life and civic activity in civil society and a democratic state governed by the rule of law in classes on any subject of the school curriculum" [2]. The use of interactive technologies makes certain demands on the structure of lessons. As a rule, these are: motivation; announcement, presentation of the topic and expected learning outcomes; providing the necessary information; interactive exercise - the main part of the lesson; summarizing, evaluating the results of the lesson. [1, p. 18]. Focused on the development and assertion of personality is group work as one of the interactive technologies for organizing educational activities. The music lesson washes away the great power of influence on the inner and spiritual world of students, awakens interest in music, the need to communicate with it. Gradually, in each lesson, children learn to understand that music is closely linked to life, that is, that there is a strong connection between music and life. There are requirements for the implementation of interactive teaching methods, non-compliance with which can reduce their effectiveness to zero. It is necessary to conduct an introductory lesson, because students are completely unfamiliar with such methods of work that dramatically change the established style of learning. In this lesson it is necessary: firstly, to explain clearly and clearly what is interactive learning, and secondly, to inform students and work out with them the rules of working in groups, compiled in an understandable form. The essence of interactive learning is that the learning process takes place under conditions of constant, active interaction of all students. Researchers O. Pometun and L. Pyrozhenko divided interactive teaching methods into four groups: group, frontal learning, in-game learning and discussion [3]. You need to create and maintain a friendly atmosphere in the team. You should prepare honestly for each lesson. 
"Easy" in the form of interactive learning is extremely difficult for the teacher, because to achieve discipline and attention through "sit quietly!" impossible. In addition, it is necessary to plan the implementation, to do it gradually. All students should be involved in the work to one degree or another. In fact, strong students as well as individuals with a high level of contact will be more active than closed and weak ones. However, you should constantly "involve" them in the work, to create situations of success.

In the process of applying interactive learning, various problems and difficulties constantly arose. We consider it expedient to present them to show the practical side of interactive learning. So, typical problems: the student often does not have his own opinion, and if he has, he is afraid to express it openly, to the whole class. The students themselves explain it this way: "Is my opinion valuable?"; Often students do not know how to listen to others, objectively evaluate their opinions and decisions; The student is not ready in the process of discussion to change his mind, to compromise; It is difficult for them to be mobile, to change the situation, methods of work; Difficulties in small groups: leaders try to "pull" the group, and weaker students immediately become passive; There are often expressions of openly anti-social opinions in order to gain "authority": "You yourself said that every opinion is valuable, and I think so and you will not convince me!". However, with skillful implementation, interactive teaching methods allow to involve all students in the class, contribute to the development of socially important skills of teamwork, interaction, discussion, discussion [4, p. 17].

Thus, during interactive learning, the student becomes not an object but a subject of learning, he feels an active participant in events and his own education and development. This forms students' intrinsic motivation to learn and encourages them to self-development and self-observation. The driving force of innovation is the teacher as a creative person who has ample opportunities and unlimited field for innovation, because in practice he can experiment and see the effectiveness of teaching methods.

\section{Literature}

1.State standard of primary general education // Primary school. - 2011. - P. 18.

2.Zakharchuk T.V. Innovative learning technologies in the modern school. - Ukrainian scientific journal "EDUCATION OF THE REGION". $136 \mathrm{p}$.

3.Pometun O., Pirozhenko L. Interactive learning technologies: theory and practice. - K., 2012. -

4.Smirnov S. A. Pedagogy. - M., 2012. - 204 p. 


\title{
ECONIMICS SCIENCES
}

\section{USE OF CRM-SYSTEMS IN ENTERPRISE ACTIVITIES TOURIST INDUSTRY}

Tetiana Marusei,

$\mathrm{PhD}$ in Economic, Associate Professor of the Department of tourism and hotel-restaurant business chair, economical department, Ivan Ogiyenko Kamyanets-Podilsky national university

\begin{abstract}
The article deals with the essence of CRM and the necessity of their use in business enterprises of the tourism industry. The main advantages and disadvantages of their use in the business tourism industry to build relationships with customers.
\end{abstract}

Keywords: marketing, CRM-system, customer management, enterprises tourism industry, customer relations.

Today in the tourist market of Ukraine there is a situation when the offer goods and services are quite large and diverse, and the demand for them is the same to the extent necessary is not satisfied. This is primarily due to existence of a large enough number of enterprises in the tourism industry, which provide accommodation, food, recreation, tour booking, excursion and recreational services, etc. According to some analysts, the market oversaturated with such entities, as only $40 \%$ of the population organizes their travels through travel agencies, the other $60 \%$ of vacationers alone organize your vacation.

In such conditions before the enterprises of the tourist industry more and more the problem is not only the coverage of new target audiences, establishing contacts with potential consumers, but also maintaining connections with existing customers and maximum satisfaction of their needs. In this In this aspect, the ability to quickly and accurately predict desires is very important consumer and in time to be able to identify the main priorities that he will be guided in choosing a way to meet their needs. In modern one of the most effective marketing tools that can provide establishing such a contact is a CRM system, the purpose of which is management customer relationships.

CRM-system may be considered as a set of technologies, in other words a set of apps that are conformed to overall business logic and integrated into IT environment of the enterprise, forming a single database. CRM system is widely used by companies in parallel with ERP system, or at least CRM module is used as a part of the ERP II system. Customer relationship management software enables automation of business processes associated with marketing, sales and service. As a result, we get the ability to provide customers with personalized offers, making allowances to their favorable time for an agreement or most convenient channel of communication. CRM system facilitates coordination among various departments, providing them with a platform for interacting with customers. Such approach prevents departments of marketing, sales and service from lack of coordination, concerting their actions to client's overall vision. Moreover, like any other information system, CRM can significantly speed the stream of data, increasing its reliability, which in turn improves the effectiveness of request responses and cash management, and keep down expenses [8, p. 176-178].

With the development of market economy in an increasingly competitive environment companies are forced to seek for competitive advantages. These advantages can be provided by either internal production efficiency, or better, compared to peers, focus on the market. CRM as an information system helps businesses in development of effective market orientation. These systems are designed to create a large base of "loyal" customers that will secure the competitive edge for the company.

CRM (Customer Relationship Management) is the current trend in automation management, 
designed to regulate relationship with customers. However, the extent of these technologies in Ukraine is limited. According to mentioned definition, CRM creates the ability to unify critical customer data from multiple of sources and integrate them. Therefore, CRM technologies predominantly determine possibilities for information collecting, processing and use.

In recent years, CRM systems have been increasing in popularity. However, the key objective of all these technologies is to provide continuous customer feedback, related to promotion, sale and support of products and services, i.e. operating activity. Even though these activities stay a very important part of CRM technology, they can't provide the opportunity to explore the full potential of customer orientation strategy. Instruments, providing both operational and strategic analysis, as well as assessment of market situation and support in decision-making management are no less important for CRM strategy implementation. The lack of such tools in CRM systems is one of the main reasons for the failure of implementation of this kind of projects.

The term CRM traditionally is used to reflect not only information systems that contain functions of customer relations management, but also customer-orientation strategy itself. The essence of this strategy is the integration of multiple sources for gaining customer data, information about sales, responses to marketing activities, market trends [1].

Modern CRM is aimed at studying the market and specific customer needs. On the basis of the data and information gathered, companies develop new products or services, and, as a result, improve their financial performance.

Before 1993, CRM market was divided into two main areas - Sales Force Automation (SFA) and Customer Service (CS). Primary purpose of the sales force automation systems was to provide sales representatives with the tool for customers 'proximity points' management, as well as development and realization of sales schedule. Over time, these systems have been supplemented by management functions. In practical terms, this means supporting sales and marketing techniques of the company, and reaching cooperation between business units, i.e. customer support service or maintenance department.

Today, the primary focus of CRM systems is managing the operational CRM and CRM interactions. IT-solutions for this area provide businesses a means of collecting a complete history of customer relationship, possessing the latest information about sales, problem solving in customer service, and effectiveness of marketing. The availability of such information can be of great benefit in determining the state of the enterprise market and identifying strategies. By refusing to use analytical methods businesses limit their own profit opportunities.

The market of CRM software supplies products that may or may not contain an analytical module. The last ones use analytic tools, provided by original software developers. This approach is rather common, but there are two major limitations:

1) Software packages integration complexity. Of course, marketing manager doesn't have to import data from programs manually. However, ensuring of software packages close integration on the information system level can be very expensive;

2) The use of each universal program requires profound knowledge in this area.

CRM technologies appear to replace marketing planning, reducing its labor intensity and, as a result, increasing product availability. CRM-technology fit into the overall process of marketing planning, in a view of the fact that it may be described as an intensive process, taking inputted company and market information and converting it to company development strategy.

Marketing planning methodology has two key components: data collection and processing of managerial and marketing decisions. However, these processes are specific to each company. They depend on its type, technological capabilities and traditions. Well-structured approach to data collecting process allows getting most customer information during daily work of the company departments. What should be understood is that the database in itself, without analytical tools that form an integral part of CRM technology, gives nothing.

There are two types of CRM apps: OLAP (online analytical processing - data analysis in real time) and Data Mining (working out of data). The first type includes tools enabling a user to easily and selectively extract and view data from required point of view. The second type includes graphics, mathematical and statistical tools that help to find certain patterns in data arrays.

The next step of marketing planning is to formulate marketing objectives and strategies. Marketing strategies have the fundamental goal of sales performance (revenue, profit, market share) increasing, identifying the means by which the company is going to achieve these goals. The major marketing 
management decisions can be classified in one of following categories (the Four Ps Marketing Mix): product, price, promotion (advertising, merchandising), and place (the structure of sales). In the process of defining and agreeing of marketing objectives and strategies the following analytical CRM tools are widely used: forecasting, what-if analysis, portfolio analysis, SWOT-analysis and more. These tools solve these types of problems:

- Calculation of target profit and profitability of products, customers, and distribution channels;

- Demands analysis for particular products;

- Sales forecast that take into account various factors affecting demand;

- Optimization of company's products and services portfolio;

- Selecting effective pricing strategies for specific market segments [6].

The final stage of marketing planning is program developing. Marketing program is clearly defined set of marketing activities with strictly prescribed goals and budget. Operational CRM includes the whole class of systems for marketing tactics development. They are particularly effective for marketing activities developing and promotion. These tools help to plan appropriate actions and monitor their implementation. Properly organized data collection with a help of CRM system provides more than enough information for audit conducting. Therefore, marketing programs developing must take into account the marketing activities effectiveness for the previous planning period, at the same time not requiring additional investments for foreign market research.

However, marketing goes beyond CRM systems. Focusing only on CRM, the company will lose a lot of market opportunities associated with access to other consumer markets. Moreover, it's impossible to win the competitive struggle, basing on a single case study with no regard to competitive intelligence. Marketing planning programs, alongside with analytical CRM provide this kind of analysis.

The key problem of most planning programs is that they need to combine large amounts of data of all business units, such as data production, marketing, external market monitoring, for their quality performance. As a result, marketing programs designed to plan, can implement only the general marketing planning methodology, demanding to input the results of another researches. At best, these programs may offer tools for analysis, requiring manual input of large amounts of data, collected by users themselves.

Some marketing modules of corporate information systems provide a number of reports within the data, collected by these systems. Typically, enterprise systems keep only inner company data, such as sales, shipping, financial flows. Marketing information systems may also collect information on potential customers, competitors, and macro-environment. In addition, marketing management system should include analytical modules for processing this information and bringing it into a form, suitable for decision-making.

The use of CRM-systems in the tourism industry allows optimally plan and conduct marketing activities, manage resources and marketing costs. With their help, managers can plan sales, organize transparent transaction management and optimize sales channels. This significantly affects the performance and provides effective management of work not only of the personnel, but also with clients. System keeps a complete history of communication with customers, helps sales departments analyze their behavior, create and sell products that need the latter.

The introduction of a CRM system allows a travel company to get the following advantages: increased return on contact with the consumer; receiving reliable information about the interests and wishes of the client through his login to site; the ability to integrate the system with other operating systems; receiving basic information on making sound management decisions; individual approach to each client with the maximum consideration of it needs; identifying the relationship between customer interests and the volume of implementation their purchases; prompt response to changes in customer needs and subordination of the system to their satisfaction.

The introduction of a CRM system allows a travel company to get the following advantages: increased return on contact with the consumer; receiving reliable information about the interests and wishes of the client through his login to site; the ability to integrate the system with other operating systems; receiving basic information on making sound management decisions; individual approach to each client with the maximum consideration of it needs; identifying the relationship between customer interests and the volume of implementation their purchases; prompt response to changes in customer needs and subordination of the system to their satisfaction. Therefore, for tourism businesses industry it is advisable to implement such construction systems as soon as possible 
mutually beneficial relationships with customers aimed at improving efficiency and profitability of their activities by attracting and retaining profitable customers. The sooner the CRM system starts collecting information about its customers, the earlier it will be possible to plan activities for the development and implementation of a certain a product that will be in demand.

\section{References}

1.Albitov, A. (2014), “CRM (Customer Relationship Management)”, available at: http://www.cfin. ru/itm/crm-review.shtml, (access date June 11, 2016).

2.Greenberg, Paul (2013), CRM so skorostyu sveta. Privlecheniye i uderzhaniye kliyentov v realnom vremeni i cherez Internet [CRM at the Speed of Light. Attracting and retaining customers in real time over the Internet], Translated by V. Agapova, Simvol-Plyus, St.-Peterburg, Russia, 526 p.

3.Ilicheva, I. V. (2012), Marketingovyye tekhnologii [Marketing technology], tutorial, UlGTU, Ulyanovsk, Russia, $158 \mathrm{p}$.

4.Payne, Adrian. (2007), Rukovodstvo po CRM. Rukovodstvo po sovershenstvovaniyu menedzhmenta kliyentov [Handbook of CRM: Achieving Excellence in Customer Management], Translated by S. Krivosheine, Grevtsov Pablisher, Minsk, Belarus, 384 p.

5.Sinilo, L. (2006), "Harder than it sounds - the introduction of CRM", Novyi Margeting, no. 3, pp. $87-85$.

6.Terrasoft (2014), "Enterprise Management Systems", available at: http://www.terrasoft.ua, (access date June 10, 2016).

7.Crmonline (2015), "CRM-system features", available at: http://www.crmonline.ru/crm/ functions/, (access date June 08, 2016).

8.Sharapa, O. M. (2009), "Managing customer relationships through the implementation of CRMsystems as part of effective business", Aktualni problemy ekonomiky, no. 7 (97), pp. 175-183.

9. Yaroshenko, V.A., Podolnaya, V.V. and Geseleva, N.V. (2015), "The role of the CRM-system in the marketing activity of the enterprise", VISNYK KNUTD, no. 3 (87), pp. 81-86. 
Primedia E-launch LLC

International scientific and practical conference cutting edge-science 2021. Primedia E-launch LLC January, 2021 Shawnee, USA. 75 pp.

ISBN 978-1-64945-245-0

DOI: http://doi.org/10.37057/U_7 